\title{
Experimental Studies on Bioregeneration of Activated Carbon Contaminated With Hydrocarbon
}

\author{
${ }^{1}$ Ameh, C.U., ${ }^{2}$ Jimoh, A., ${ }^{3}$ Abdulkareem, A.S. and ${ }^{4}$ Otaru, A.J. \\ ${ }^{1}$ (Chevron Nigeria Limited, 2, Chevron Drive, Lekki, Lagos, Nigeria). \\ ${ }^{2,3 \& 4}$ (Department of Chemical Engineering, Federal University of Technology, Minna, Nigeria)
}

\begin{abstract}
The search for a more cost effective, environmentally friendly and less cumbersome process of regenerating used activated carbon in a petroleum polluted site necessitated this research work. Spent Granular Activated Carbon was regenerated having been initially characterized using cultured Pseudomonas Putida. The rate of Bioregeneration was studied by varying the volume of bacteria from $10 \mathrm{ml}, 20 \mathrm{ml}, 30 \mathrm{ml}$ and $40 \mathrm{ml}$. The regeneration temperature was also varied from $25^{\circ} \mathrm{C}$ to ambient temperature of $27^{\circ} \mathrm{C}, 35^{\circ} \mathrm{C}$ and further at 40 and $45^{\circ} \mathrm{C}$ over a period of 21 days. The regeneration experiment improved as the quantity of bacteria used increased. Increasing the temperature of regeneration also increased the rate of regeneration due to chemisorptions action. There was no significant improvement when the temperature was increased to $45^{\circ} \mathrm{C}$ suggesting that increasing temperature beyond $40^{\circ} \mathrm{C}$ would not be economical. The regenerated GAC was characterized to determine efficiency of regeneration. Bioregeneration was impacted by variation in temperature and bacteria volume. Bioregeneration spent Granular Activated Carbon is shown by the study to be an effective and cost efficient way to remediate polluted soil and still reuse the adsorbent.
\end{abstract}

Keywords: Bioregeneration, Chemisorption, GAC, Hydrocarbon and Nigeria

\section{Introduction}

Despite the huge economic benefits of oil exploitation, there are many associated primary and secondary problems that could impacted negatively on the habitants and the environment in Nigeria. Some of which include contamination of streams and rivers within the exploration and processing areas, oil spillage, destruction of forests and bio-diversity loss, gas flaring and environmental pollution (Nwankwo and Ifeadi, 1988; Bayode et al, 2011; Eregha \& Irughe, 2009). Among the outlined menaces of oil exploration and exploitation, oil spillage has been reported as one with the most significant impact (Oghifo, 2011; Afinotan \& Ojakorotu, 2009; Achebe et al, 2012; Kadafa, 2012), thus, there is the need to improve on the processes and mechanisms that can facilitate quick correction of identified spill cases.

The use of activated carbon (AC) has proven to be one of the best adsorbents for organic pollutants due to its hydrophobicity, and microporous structure (Vasilyeva et al, 2006). Addition of activated carbon to the polluted soil leads to a process of sorption and biodegradation of the pollutants. This adsorption process is suitable for use in a lot of other processes like the remediation of soils contaminated with hydrocarbon. Activated carbon successfully reduces the bioavailability of organic contaminants due to its strong sorption properties (Bucheli \& Gustafsson, 2000). Among the advantages of the use of activated carbon for oil spill cleanup is the fact that it has a high sorptional capacity with a relative low viscosity for $1 \mathrm{~g}$ of the carbon. It also possesses a high rate of sorption and can also achieve reasonable level of cleanup at a relatively lower cost without serious negative impact on the environment (Amer and Hussein, 2006). It is worthy of note however that activated carbon will not remove any heavy metal from the cleanup site and it will also lose its sorptional capacity when it becomes saturated. The use of activated carbon as a cleanup medium provides a less costly option compared to the other available techniques (Sivakumar et al, 2011; Stenzel \& Merz, 1989; Vasilyeva et al, 2006).

Bioregeneration is widely used in solving problems of pollutant contamination of the soil and water body. According to Coelho et al (2006), the main disadvantage inherent in the use of activated carbon to achieve the above is the issue of contamination by the pollutant. There are various methods that can be used to remove the pollutants from the adsorbents. The advantage of using biological regeneration over thermal as espoused by Coelho et al (2006) include the avoidance of loss of volatile compounds as well as pyrolysis of the non-volatile adsorbents at higher temperature.

The use of activated carbon plays a vital role in the cleanup of spill sites, the attendant secondary pollution created by its dumping can be eliminated by regenerating the adsorbent. The process of thermal regeneration is very expensive and energy consuming. Hazardous by-products are also produced and there is always tendency of imposing or introducing negative effect(s) on natural properties of the product. These have necessitated the search for a more cost effective, environmentally friendly and less cumbersome process of 
regenerating used activated carbon. It is against this background that experimental studies on Bioregeneration of activated carbon contaminated with hydrocarbon is imperative.

\section{Research Methodology}

Three samples of polluted soil of different concentration of hydrocarbon were treated with virgin activated carbon. Characterization of the granular activated carbon was carried out by determining it surface area, bulk density, pore volume, $\mathrm{pH}$, moisture content, ash content and particle size before and after regeneration. The optimum degradation temperature was determined from literature. The total hydrocarbon concentration of the used activated carbon was determined and the saturated activated carbon was extracted from the soil sample using a physical sieve of $1.7-2.4 \mathrm{~mm}$. This is necessary because the particles size of granular activated carbon is larger than the soil granules. Extracted used activated carbon was then treated with pseudomonas putida bacteria culture. The treatment take place in a Bioreactor set up the laboratory. The rate of hydrocarbon degeneration was measured at intervals of 24 hours for 21 days by collecting samples and testing for hydrocarbon content and concentration. Evidence of activated carbon regeneration occurred by the reduction in the total hydrocarbon content (THC) in the sample over the 21 days.

\section{Results And Discussions}

The use of Granular Activated Carbon is one of the methods in achieving site remediation. It can also be used in the removal of organic constituents in waste water due to the important advantage of not adding anything detrimental to the water (DeSilva, 2000). For economic reasons, recovering of GAC already saturated with the hydrocarbon pollutant needs to be regenerated. Amongst the various methods for achieving this, the use of bioregeneration is chosen to ensure preservation of the structure of the GAC as well as protect the environment.

The commercially obtained Granular Activated Carbon was characterized before and after use for the bioregeneration exercise as shown by the results on Table 1 . The results obtained indicated that the surface area of the virgin GAC was $738 \mathrm{~m}^{2} / \mathrm{g}$. The surface area for the regenerated GAC was measured to be $730 \mathrm{~m}^{2} / \mathrm{g}$. This implies minimal distortion and impact on the surface area of the GAC during the remediation and bioregeneration experiment. The surface area also falls within the acceptable standard range of $500-1500 \mathrm{~m}^{2} / \mathrm{g}$ (DeSilva, 2000) or $600-1200 \mathrm{~m}^{2} / \mathrm{g}$ (Jabit, 2007). The bulk density measured for the virgin GAC was $386 \mathrm{~kg} / \mathrm{m}^{3}$. After regeneration, the bulk density was measured at $379 \mathrm{~kg} / \mathrm{m}^{3}$ indicating the recovery of the quality of the GAC (SAJ Holdings SDN BDH, 2002). The pore volume of the virgin GAC was measured as $0.098 \mathrm{~cm}^{3} / \mathrm{g}$. The regenerated GAC also had a pore volume measured as $0.097 \mathrm{~cm}^{3} / \mathrm{g}$. The pore volume determines the size of molecules of the substance the GAC can adsorb (Jabit, 2007) and the results obtained indicates a high efficiency of regeneration. The value is also in alignment with the standard of $1.109 \mathrm{~cm}^{3} / \mathrm{g}$ (Hameed et al, 2006). The $\mathrm{pH}$ of the virgin GAC was measured as 6.0. After regeneration, the $\mathrm{pH}$ of the GAC was measured to be 6.4. Most of the adsorbed hydrocarbon was removed from the GAC and this manifested in the attainment of 6.4 as the pH. The $\mathrm{pH}$ of the regenerated GAC conforms to the standard of 6.0 - 7.0 (Metcalf \& Eddy, 2003) or 6.8 (Ekpete and Horsfall, 2011). The percentage moisture content was measured to be 2.72 in the virgin GAC. The regenerated GAC however has a result of 2.71 and this falls within the acceptable moisture content limit of $<5 \%$ (SAJ Holdings SDN BDH, 2002). The ash content was measured as shown on the table to be $3.69 \%$ for the virgin GAC and 3.58\% for the regenerated GAC. This falls within the range of $2-10 \%$ (Jabit, 2007) and <15\% (SAJ Holdings SDN BDH, 2002). The lower the ash value, the better the GAC for use as a adsorbent (Ekpete and Horsfall, 2011). The measured particle size for the virgin GAC and the regenerated GAC was the same with the value of $1.8 \mathrm{~mm}$.

Plates I and II pictorially show the GAC sample in its virgin state and also after regeneration respectively. 
Experimental Studies On Bioregeneration Of Activated Carbon Contaminated With Hydrocarbon

Table 1 Results on the characterization of granular activated carbon (GAC)

\begin{tabular}{|c|c|c|c|c|c|}
\hline S/No & Property & $\begin{array}{c}\text { Before } \\
\text { Regeneration }\end{array}$ & $\begin{array}{c}\text { Before } \\
\text { Regeneration }\end{array}$ & Standard & Reference \\
\hline 1. & Surface area & $738 \mathrm{~m}^{2} / \mathrm{g}$ & $730 \mathrm{~m}^{2} / \mathrm{g}$ & $500-1500 \mathrm{~m}^{2} / \mathrm{g}$ & DeSilva (2000) \\
\hline 2. & Bulk density & $386 \mathrm{~kg} / \mathrm{m}^{3}$ & $379 \mathrm{~kg} / \mathrm{m}^{3}$ & $>180 \mathrm{~kg} / \mathrm{m}^{3}$ & $\begin{array}{c}\text { SAJ Holdings } \\
\text { SDN BDH } \\
(2002)\end{array}$ \\
\hline 3. & Pore volume & $0.098 \mathrm{~cm}^{3} / \mathrm{g}$ & $0.097 \mathrm{~cm}^{3} / \mathrm{g}$ & 1.109 & $\begin{array}{c}\text { Hameed et al., } \\
2006\end{array}$ \\
\hline 4. & $\mathrm{pH}$ & 6.0 & 6.4 & $6.0-7.0$ & $\begin{array}{l}\text { Metcalf and } \\
\text { Eddy (2003) }\end{array}$ \\
\hline 5. & Moisture content & $2.72 \%$ & $2.71 \%$ & $<5 \%$ (AWWA) & $\begin{array}{l}\text { SAJ Holdings } \\
\text { SDN BDH } \\
(2002)\end{array}$ \\
\hline 6. & Ash content & $3.69 \%$ & $3.58 \%$ & $<15 \%$ & $\begin{array}{c}\text { SAJ Holdings } \\
\text { SDN BDH } \\
(2002)\end{array}$ \\
\hline 7. & Particle size & $1.8 \mathrm{~mm}$ & $1.8 \mathrm{~mm}$ & N/A & N/A \\
\hline
\end{tabular}

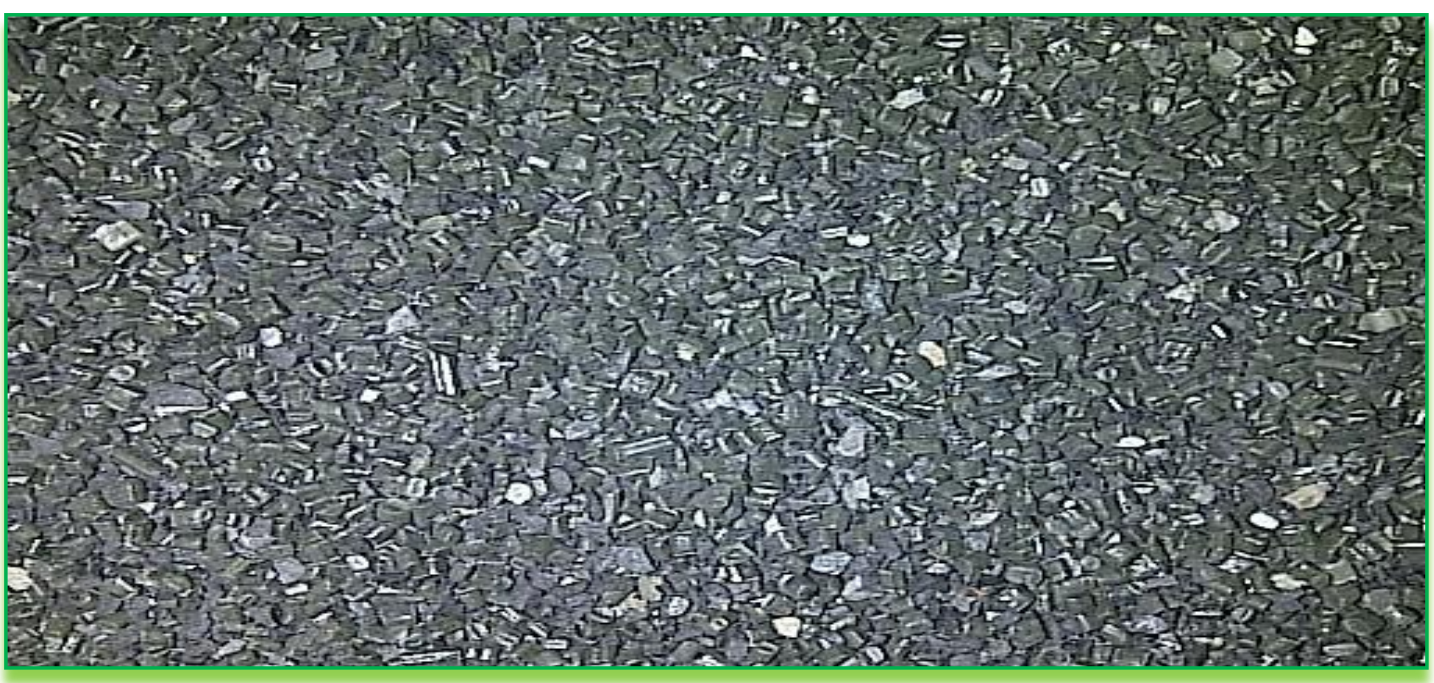

Plate I: Granular Activated carbon before remediation

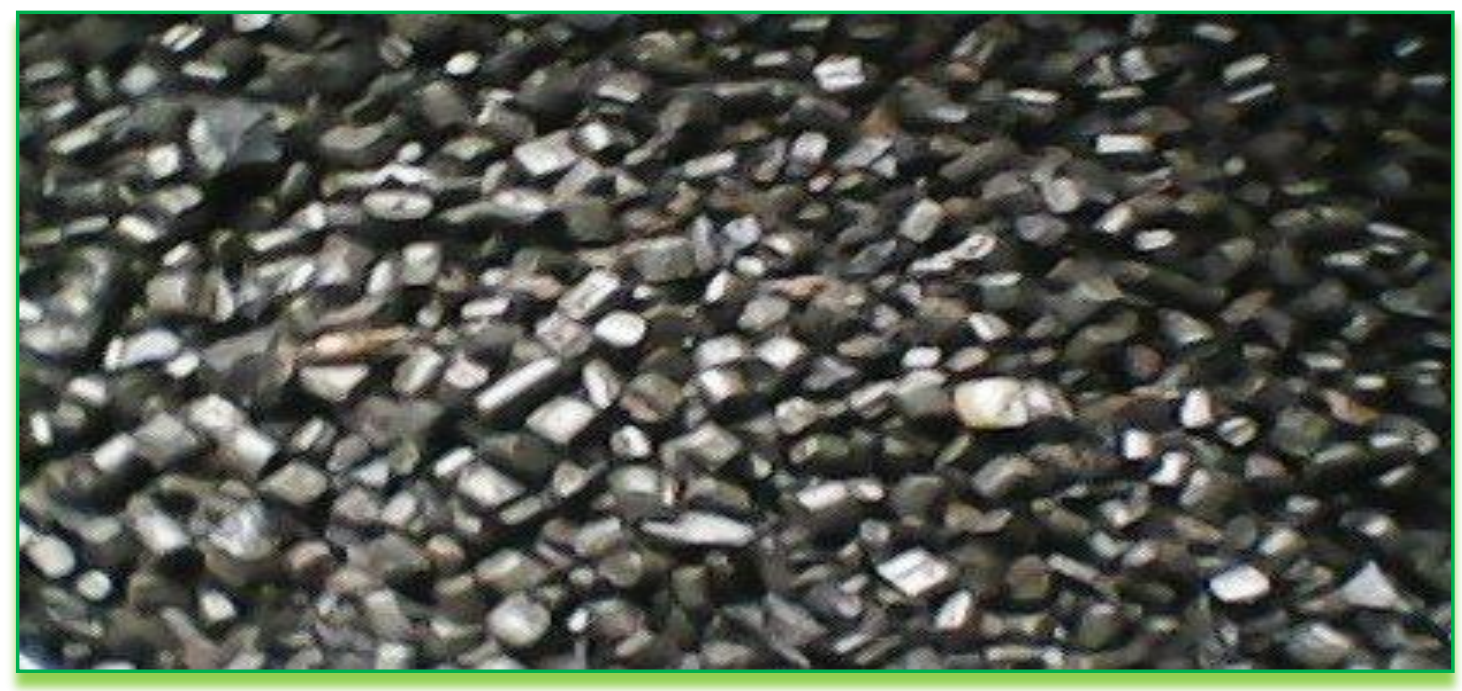

Plate II: Granular Activated Carbon after remediation 


\section{Bioregeneration Experiment with Varying Bacteria Volume}

Figure 1 is obtained from the values in Table 2. The results were obtained in the bioregeneration experiment by varying the volume of bacteria. As shown on the graph, there was a sharp decrease in THC after the first 24 hours of the experiment. This initial effect of the bacteria on the hydrocarbon was equally evident for $10,20,30$ and $40 \mathrm{ml}$ bacteria volume experiments. There is a very fast production of $\mathrm{CO}_{2}$ during the first phase of interaction between the bacteria and the hydrocarbon pollutant leading to the phenomenon above (Jonge et al, 1995). It also brings to the fore the fact that the volume of substrate as well as the kinetics of desorption of the hydrocarbon decreases as the contact time between both increases (Jonge et al, 1995). However, significant differences were noticed from day two to the twelfth day between the rate of desorption in the various samples for the bioregeneration experiment. The decrease in THC for the 10 and $20 \mathrm{ml}$ bacteria volume became very slow while the rate of decrease was very evident for the 30 and $40 \mathrm{ml}$ bacteria volume. The reason for this is due to the presence of more bacteria considering the volume used. By implication, the samples with lower volume of bacteria had their bacteria used up earlier thereby reducing the rate of desorption over the same period of time. After day twelve, there was noticeable decrease in THC for all bacteria volume. On the last day of the experiment, the final THC for the 10, 20, 30 and $40 \mathrm{ml}$ bacteria volume was 7.308, 1.988, 0.526 and 0.339 respectively. It was evident that increasing the concentration of the micro organism would increase the efficiency of bioregeneration within the same time duration as confirmed by Nath et al (2011). At $40 \mathrm{ml}$, the rate of decrease in THC was steady and evident through the duration of the experiment.

Table 2 Variation of bacterial volume in saturated GAC $(100 \mathrm{~g})$

\begin{tabular}{ccccc}
\hline & Bact. $10 \mathrm{ml}$ & Bact. $20 \mathrm{ml}$ & Bact. 30ml & Bact. 40ml \\
\hline INITIAL & 25.48 & 25.48 & 25.48 & 25.48 \\
$4 / 5 / 15$ & 23.930 & 23.880 & 22.914 & 22.271 \\
$5 / 5 / 15$ & 23.701 & 23.820 & 22.401 & 21.508 \\
$6 / 5 / 15$ & 23.462 & 23.510 & 21.987 & 20.333 \\
$7 / 5 / 15$ & 23.255 & 23.070 & 21.533 & 20.164 \\
$8 / 5 / 15$ & 22.794 & 22.820 & 21.188 & 19.897 \\
$9 / 5 / 15$ & 22.749 & 22.400 & 21.110 & 19.016 \\
$10 / 5 / 15$ & 22.708 & 22.366 & 21.102 & 19.000 \\
$11 / 5 / 15$ & 22.688 & 22.363 & 20.001 & 18.582 \\
$11 / 5 / 15$ & 22.645 & 22.358 & 20.668 & 18.133 \\
$12 / 5 / 15$ & 22.617 & 22.351 & 20.183 & 17.674 \\
$13 / 5 / 15$ & 22.585 & 22.346 & 20.112 & 17.611 \\
$14 / 5 / 15$ & 22.500 & 22.341 & 20.011 & 17.489 \\
$15 / 5 / 15$ & 22.466 & 22.100 & 19.600 & 17.066 \\
$16 / 5 / 15$ & 20.771 & 19.886 & 16.981 & 14.591 \\
$17 / 5 / 15$ & 18.708 & 17.237 & 13.660 & 11.796 \\
$18 / 5 / 15$ & 16.931 & 16.944 & 10.814 & 8.844 \\
$19 / 5 / 15$ & 15.884 & 14.188 & 7.716 & 5.533 \\
$20 / 5 / 15$ & 14.930 & 11.894 & 5.842 & 2.994 \\
$21 / 5 / 15$ & 13.533 & 9.629 & 3.770 & 1.877 \\
$22 / 5 / 15$ & 11.220 & 6.535 & 1.077 & 1.087 \\
$23 / 5 / 15$ & 9.781 & 3.358 & 0.933 & 0.621 \\
$24 / 5 / 12$ & 7.308 & 1.988 & 0.526 & 0.339 \\
\hline
\end{tabular}




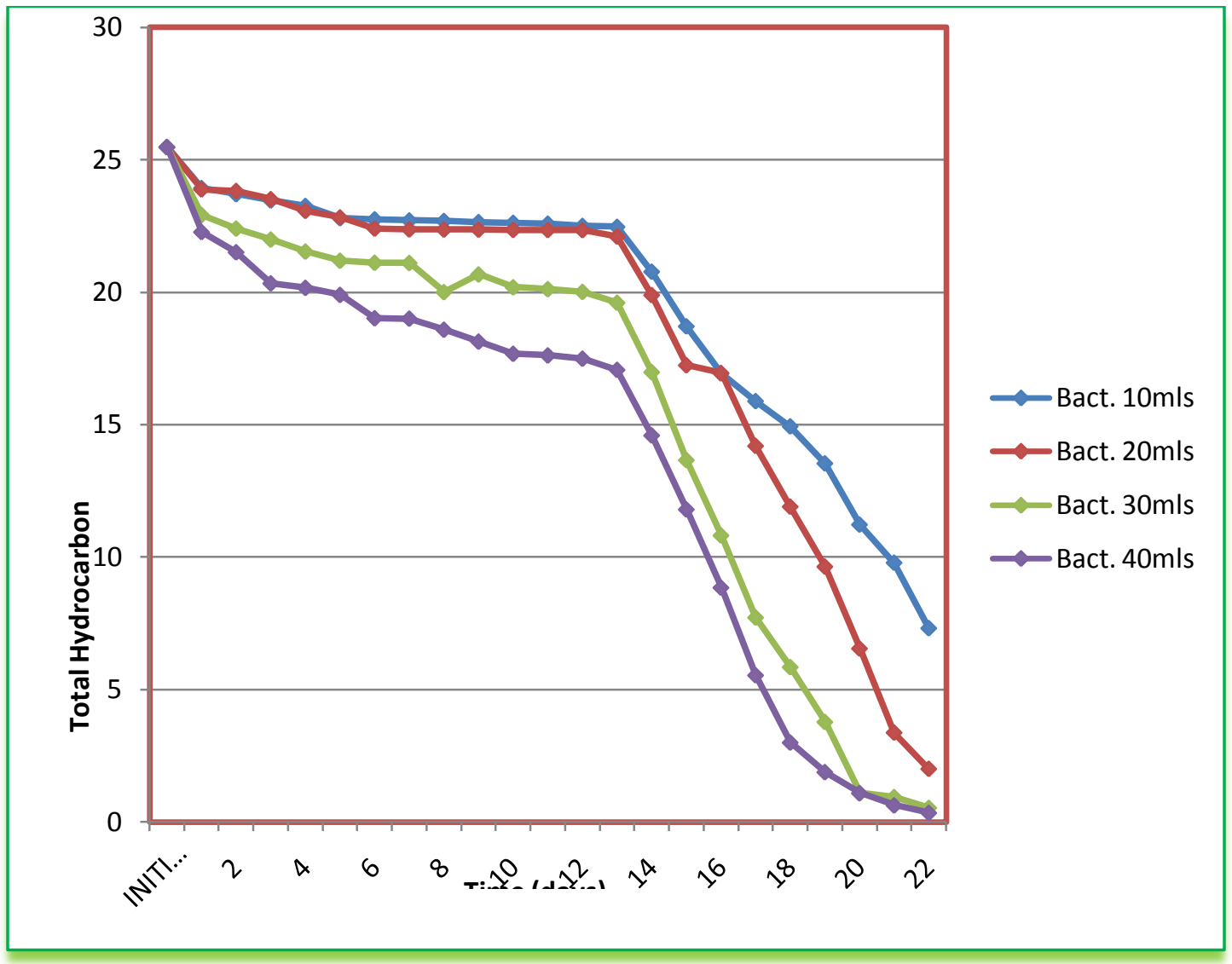

Figure 2: Bioregeneration at various volume of bacteria

\section{Bioregeneration at Varying Temperatures}

The Figure 2 below is developed from the Table 3. The graph shows the impact of change in temperature on the rate of bioregeneration. The initial THC was 24.349 for all the experimental temperatures. At $27^{\circ} \mathrm{C}$ which was the ambient temperature, there was no significant drop in THC until the 6th day. This lag phase is possibly due to the inhibitory effect of the phenol constituent in the hydrocarbon (Ullhyan \& Ghosh, 2012). Noticeable drops in THC content were observed at 25 and $35^{\circ} \mathrm{C}$ and this was consistent for the 21 days of the experiment. Increasing the temperature above the ambient of $27^{\circ} \mathrm{C}$ led to increase in the regeneration. This could be attributed to chemisorption (Lashaki et al, 2012). Final THC for the 25,27 and $35^{\circ} \mathrm{C}$ were $0.785,0.599$ and 1.535 respectively. There was need to probe the impact of temperature further considering that $25^{\circ} \mathrm{C}$ was below ambient and at ambient temperature, there was an unfavourable impact on the bacteria for the first six days of lag phase (Ullhyan \& Ghosh, 2012).

Table 3 Bioregeneration at Different Temperatures

\begin{tabular}{cccc}
\hline & $\mathbf{3 5}^{\mathbf{0}} \mathbf{C}$ & $\mathbf{2 5}^{\mathbf{0}} \mathbf{C}$ & $\mathbf{2 7}^{\mathbf{0}} \mathbf{C}$ \\
\hline INITIAL THC & 24.349 & 24.349 & 24.349 \\
$6 / 4 / 12$ & 20.934 & 20.188 & 24.344 \\
$7 / 4 / 12$ & 19.880 & 18.835 & 24.338 \\
$8 / 4 / 12$ & 19.839 & 18.196 & 24.334 \\
$9 / 4 / 12$ & 19.274 & 17.886 & 24.214 \\
$10 / 4 / 12$ & 19.175 & 17.513 & 24.166 \\
$11 / 4 / 12$ & 17.800 & 15.159 & 22.616 \\
$12 / 4 / 12$ & 15.734 & 12.228 & 18.980 \\
$13 / 4 / 12$ & 13.990 & 9.741 & 16.841 \\
$14 / 4 / 12$ & 13.400 & 9.212 & 15.002 \\
$15 / 4 / 12$ & 12.656 & 8.884 & 13.629 \\
$16 / 4 / 12$ & 11.172 & 7.808 & 12.254 \\
$17 / 4 / 12$ & 9.534 & 5.791 & 11.060 \\
$18 / 4 / 12$ & 7.877 & 4.664 & 8.361 \\
$19 / 4 / 12$ & 6.690 & 3.990 & 6.574 \\
\hline
\end{tabular}




\begin{tabular}{llll}
\hline & & & \\
$20 / 4 / 12$ & 5.880 & 2.830 & 5.080 \\
$21 / 4 / 12$ & 4.109 & 2.526 & 3.208 \\
$22 / 4 / 12$ & 3.770 & 1.944 & 2.894 \\
$23 / 4 / 12$ & 3.502 & 1.606 & 1.979 \\
$24 / 4 / 12$ & 2.183 & 1.207 & 1.526 \\
$25 / 4 / 12$ & 1.774 & 0.962 & 0.880 \\
$26 / 4 / 12$ & 1.535 & 0.785 & 0.599 \\
\hline
\end{tabular}

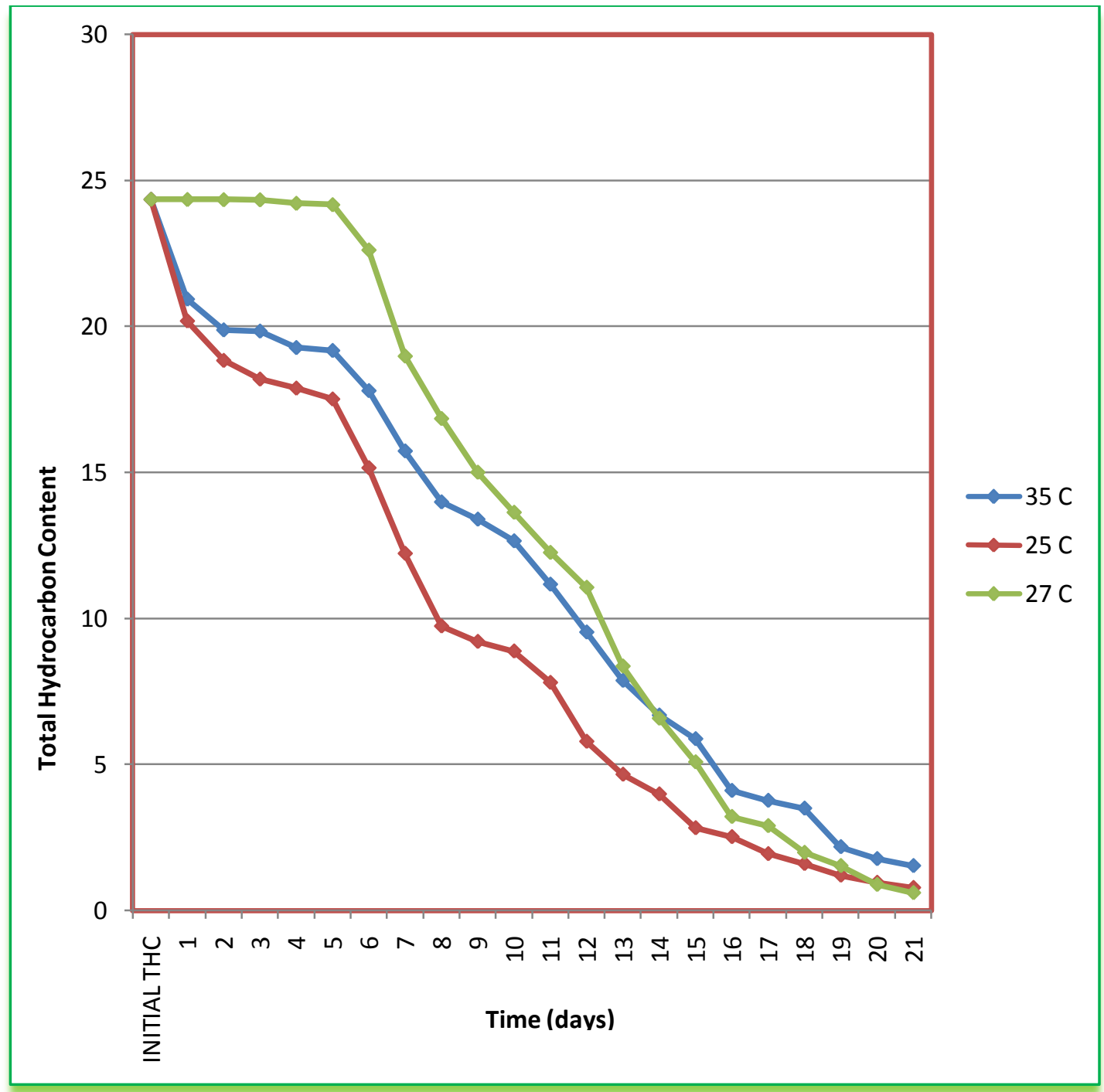

Figure 2: Bioregeneration at various temperatures

As mentioned above, there was need to further study the impact of higher temperature on the rate of bioregeneration. The final THC at $35^{\circ} \mathrm{C}$ was used as the initial THC for the extended experiment at 40 and $45^{\circ} \mathrm{C}$. The results shown on Figure 3 shows that at $45^{\circ} \mathrm{C}$, there was initially no significant impact for about 10days unlike the situation at $40^{\circ} \mathrm{C}$ where noticeable and steady decrease in THC was observed all through the experiment. At the end of the experiment on the 21 st day, the final THC was almost equal for both temperatures. The optimum experimental temperature for bioregeneration is suggested to be $35^{\circ} \mathrm{C}$ to $45^{\circ} \mathrm{C}$ (Lashaki et al, 2012). It is important to consider the energy used at $45^{\circ} \mathrm{C}$ and associated cost if same regeneration efficiency can be achieved at $40^{\circ} \mathrm{C}$. 


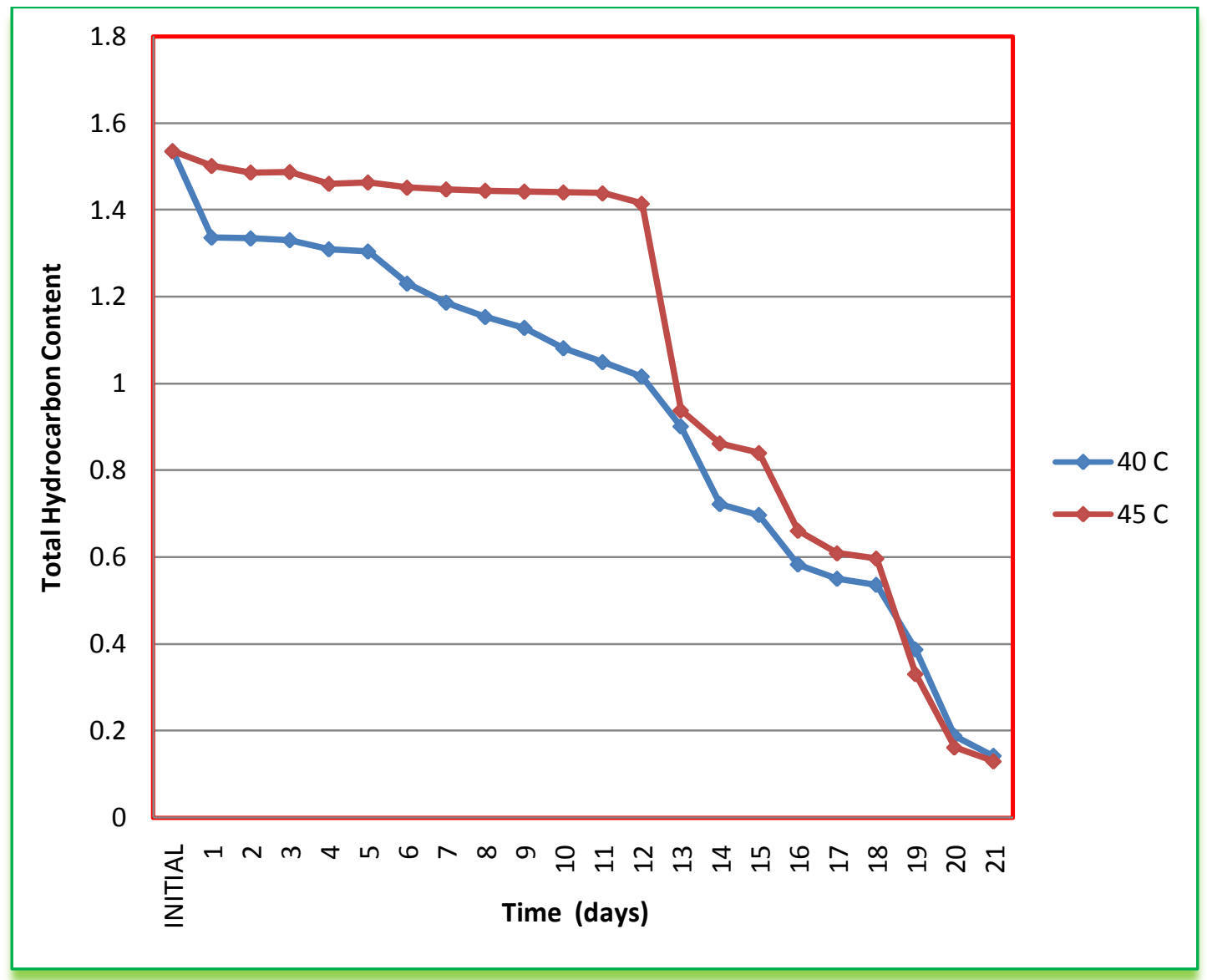

Figure 3: Bioregeneration expanded to 40 and $45^{\circ} \mathrm{C}$

\section{Conclusions}

Bioregeneration is very effective in recovering spent granulated activated carbon (GAC) for reuse considering the quality of the regenerated GAC in comparison to the virgin sample. Increasing the volume of bacteria increased the rate of Bioregeneration. Also, temperature plays an important role in Bioregeneration efficiency and increasing the temperature improved the efficiency in as much as it is beyond the temperature that will incapacitate the bacteria colony. Effective Bioregeneration was achieved at $40^{\circ} \mathrm{C}$ as such it is concluded that increasing the temperature of Bioregeneration to $45^{\circ} \mathrm{C}$ was not cost effective.

\section{Acknowledgments}

My immense gratitude goes to my Project Supervisor, Dr. Abdulfatai Jimoh, my co-Supervisor, Dr. A. S Abdulkareem who was always available to support this cause from the very first day. I feel delighted that your support has brought this dream to fruition.

\section{References}

[1]. Achebe, C. H., Nneke, U. C \& Anisiji, O. E (2012): Analysis of Oil Pipeline Failures in the Oil and Gas Industries in the Niger Delta of Nigeria. Published in the proceedings of the International MultiConference of Engineers and Computer Scientists, 2012. Vol. II. March 2012.

[2]. Afinotan, L. A \& Ojakorotu, V (2009) The Niger Delta Crisis: Issues, Challenges and Prospects. Published in the African Journal of Political Science and International Relations. Vol. 3 (50, pp 191- 198. May 2009.

[3]. Amer, A.A. and Hussein, M. (2006): Bagasse as oil spill cleanup sorbent 2. Heavy oil sorption using carbonized pith bagasse fibre. The second International Conference on Health, Environment and Development, ICHEDII, Alexandria, Egypt.

[4]. Bayode, O. J. A., Adewunmi, E. A \& Odunwole, S (2011) Environmental Implications of Oil Exploration and Exploitation in the Coastal Region of Ondo State, Nigeria: A Regional Planning Appraisal. Published in the Journal of Geography and Regional Planning. Vol. 4 (3). pp. 110 - 121. March 2011.

[5]. Bucheli, T.D. and Gustafsson, O. (2000): Quantification of the soot-water distribution coefficient of PAHs provides mechanistic basis for enhanced sorption observations, Environmental Science and Technology, 34, 5144-5151.

[6]. Coelho, C., Oliveira, A. S., Pereira, M. F. R \& Nunes, O. C (2006): The Influence of Activated Carbon Surface Properties on the Adsorption of the Herbicide Molinate and the Bio-regeneration of the Adsorbent.

[7]. Published in the Journal of Hazardous Materials. 2006.05.062.

[8]. DeSilva, F (2000): Activated Carbon Filtration. Published in Water Quality Products Magazine. January, 2000. 
[9]. Ekpete, O. A and Horsfall, M. Jnr (2011): Preparation and Characterization of Activated Carbon derived from Fluted Pumpkin Stem Waste, Research Journal of Chemical Sciences. Vol. 1 (3). June 2011.

[10]. Eregha, P. B \& Irughe, I. R (2009) Oil Induced Environmental Degradation in the Nigeria's Niger Delta: The Multiplier Effects. Published in the Journal of Sustainable Development in Africa. Volume 11, No. 4, 2009.

[11]. Hameed, B. H., Din, A. T. M \& Ahmad, A. L (2007): Adsorption of methylene blue onto bamboo based activated carbon: kinetics and equilibrium studies. Journal of hazardous materials 141, (3), 819-825.

[12]. Jabit, N. B (2007): The Production and Characterization of Activated Carbon using Local Agricultural Waste Through Chemical Activation Process. A Master's thesis submitted to the University Sains Malaysia. June 2007.

[13]. Jonge, R. J., Breure, A. M \& Andre, J. G (1995): Bioregeneration of Powdered Activated Carbon (PAC) Loaded with Aromatic Compounds. Published in the Water Research. Vol. 30, No. 4, pp. 875 - 882.

[14]. Kadafa, A. A (2012): Oil Exploration and Spillage in the Niger Delta of Nigeria. Published in the Civil and Environmental Research. Vol. 3, No. 3, 2012.

[15]. Lashaki, M. J., Fayaz, M., Wang, H., Hashisho, Z., Philips, J. H., Anderson, J. E \& Nichols, M (2012): Effects of Adsorption and Regeneration Temperature on Irreversible Adsorption of Organic Vapors on

[16]. Beaded Activated Carbon. Published in the Environmental, Science and Technology, 2012. Volume $46 . \quad$ pp. 4083 - 4090.

[17]. Metcalf and Eddy (2003): Wastewater engineering, treatment and Re-use. John Wiley 6th Ed. $1138-1151$.

[18]. Nath, K., Bhakhar, S. M and Panchani, S (2011): Bioregeneration of Spent Activated carbon: Effect of Physico-Chemical Parameters. Journal of Scientific and Industrial Research. Vol. 70, July 2011, pp. 487 - 492.

[19]. Nwankwo, N. and Ifeadi, C.N. (1988), "Case Studies on the Environmental Impact of Oil Production and Marketing in Nigeria", University of Lagos, Nigeria.

[20]. SAJ Holdings SDN BDH (2002): Specification for Granular Activated Carbon Used for Potable Water Supply. Published by the Quality Assurance Department. May 2002.

[21]. Ullhyan, A \& Ghosh, U. K (2012): Biodegradation of Phenol with Immobilised Pseudomonas Putida Activated Carbon Packed Bio-Filter Tower. Published in the African Journal of Biotechnology. Vol. 11 (85), pp. 15160 - 15167. October 2012.

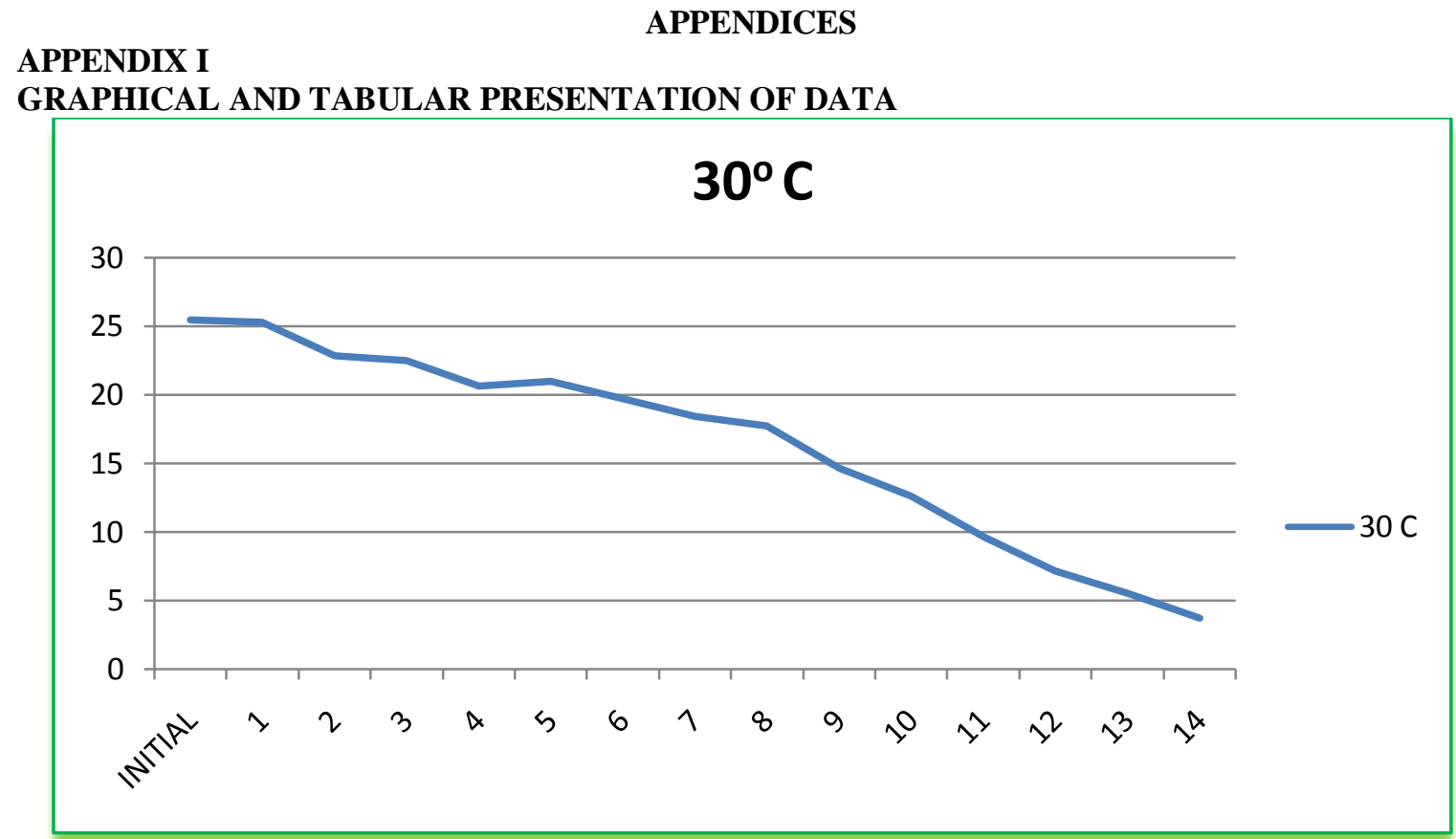

Fig I-A: Remediation at $30^{\circ} \mathrm{C}$ 


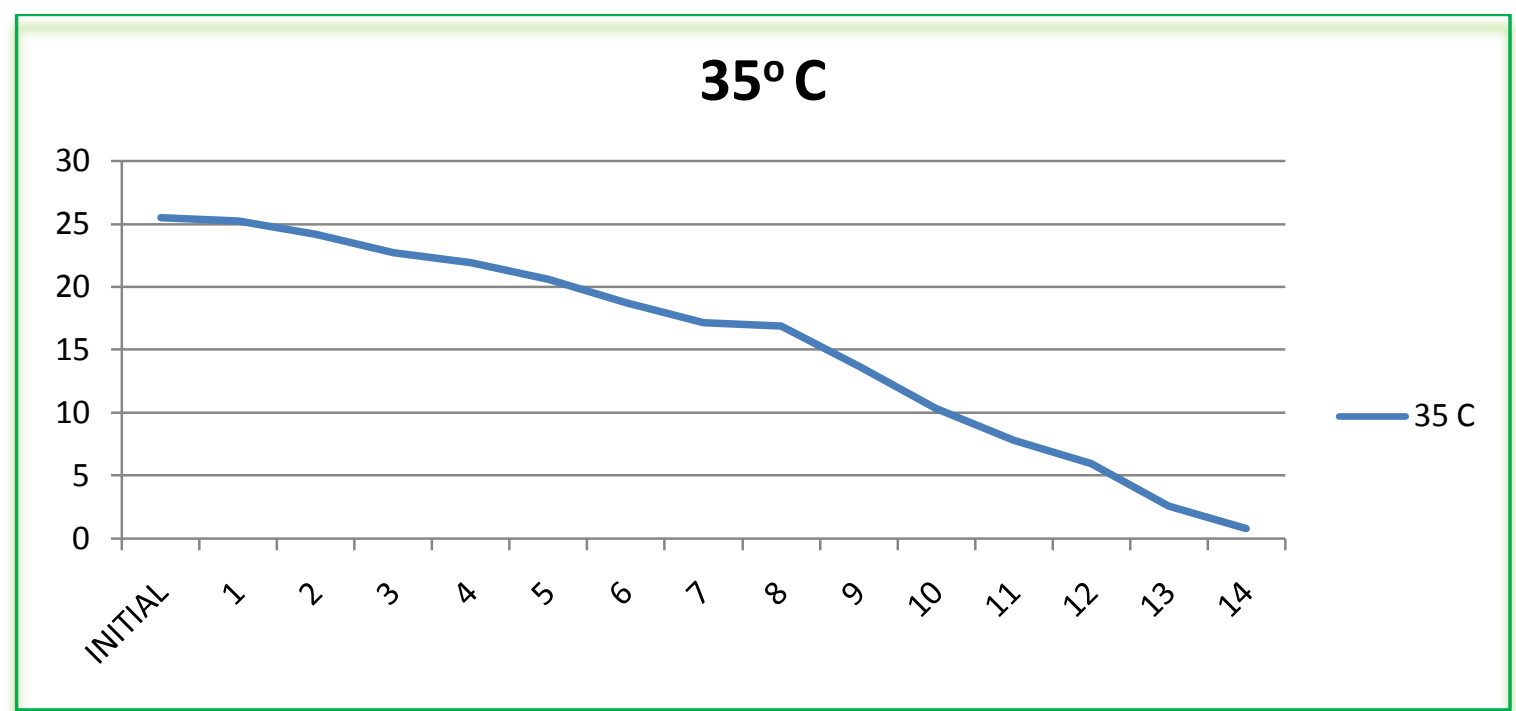

Fig I-B: Remediation @ $35^{\circ} \mathrm{C}$

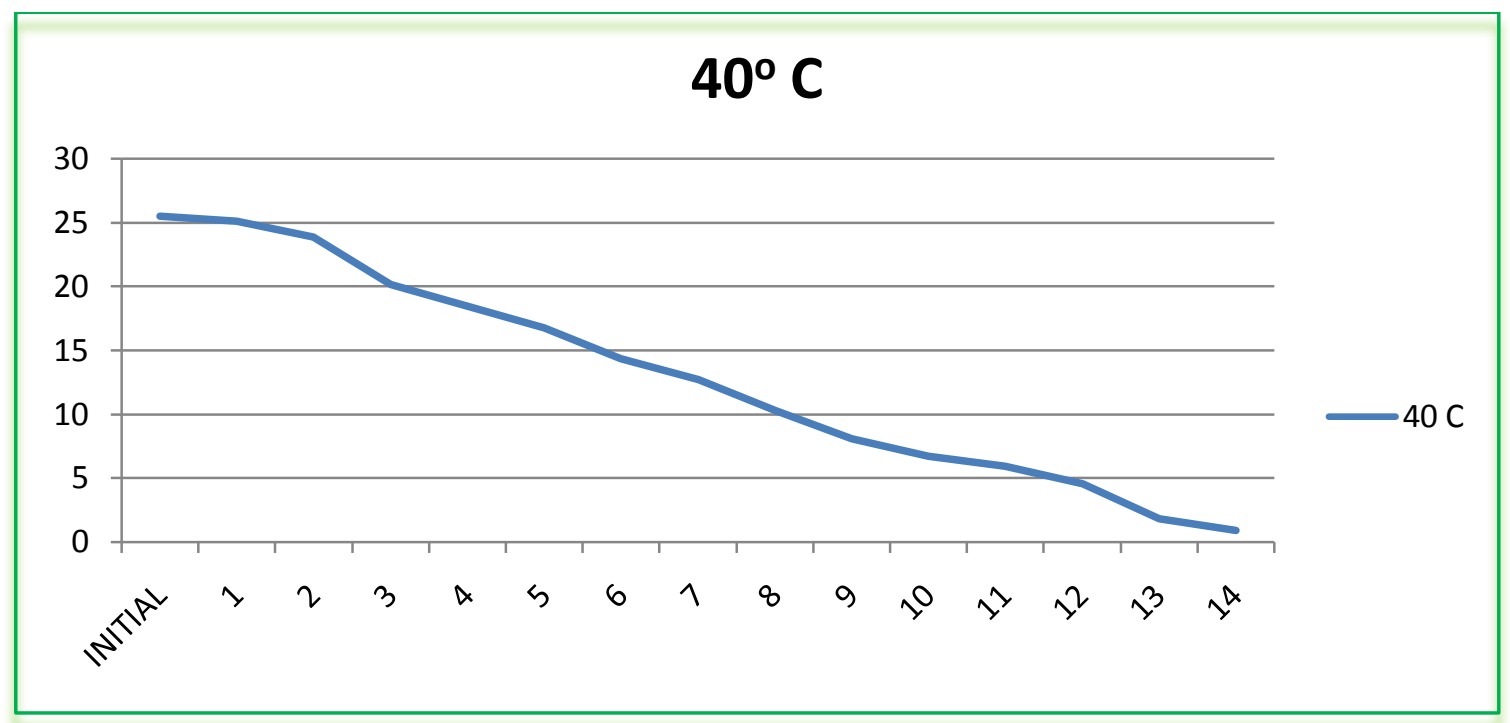

Fig I-C: Remediation @ $40^{\circ} \mathrm{C}$

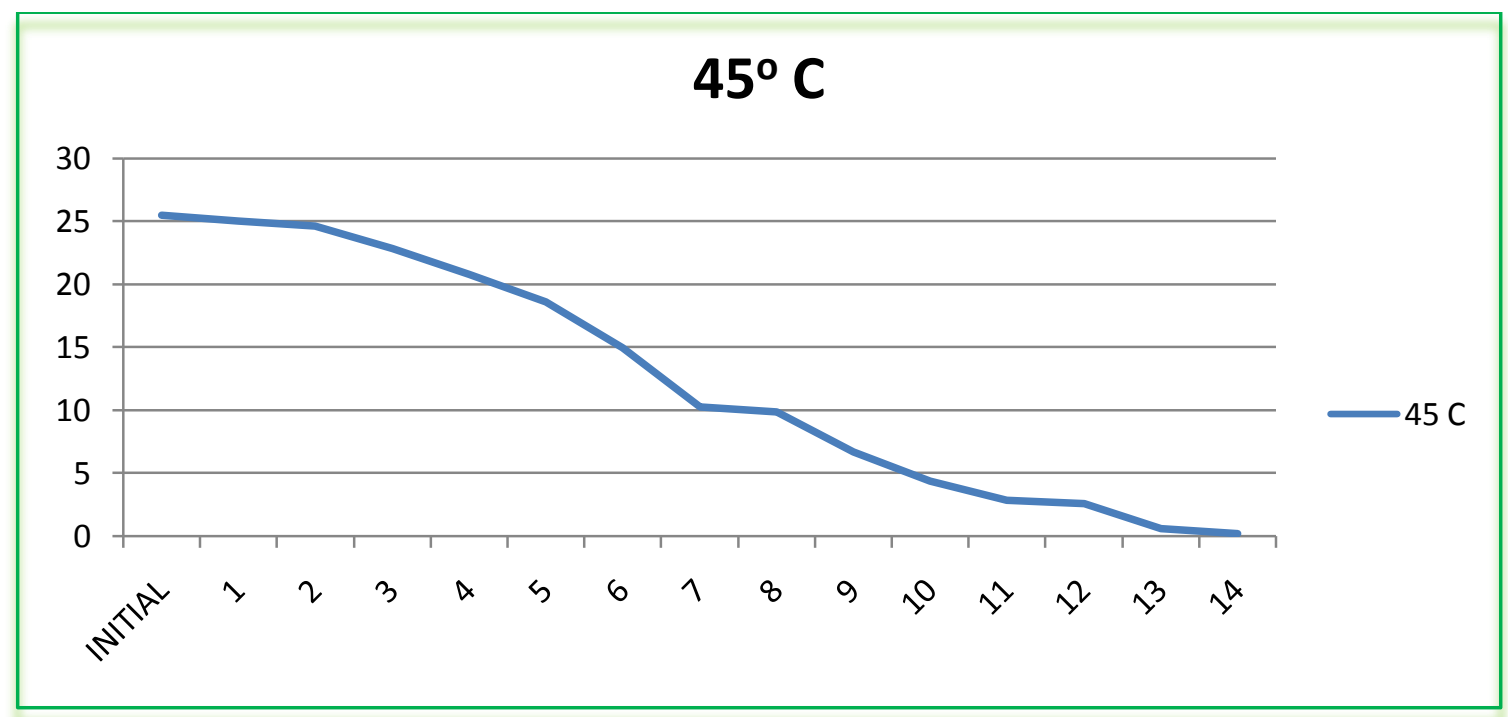

Fig I-D: Remediation @ $45^{\circ} \mathrm{C}$ 
Table I-A: Variation of bacterial volume in saturated GAC (100g)

\begin{tabular}{ccccc}
\hline & Bact. $10 \mathrm{ml}$ & Bact. $20 \mathrm{ml}$ & Bact. 30ml & Bact. $40 \mathrm{ml}$ \\
\hline INITIAL & 25.48 & 25.48 & 25.48 & 25.48 \\
$4 / 5 / 15$ & 23.930 & 23.880 & 22.914 & 22.271 \\
$5 / 5 / 15$ & 23.701 & 23.820 & 22.401 & 21.508 \\
$6 / 5 / 15$ & 23.462 & 23.510 & 21.987 & 20.333 \\
$7 / 5 / 15$ & 23.255 & 23.070 & 21.533 & 20.164 \\
$8 / 5 / 15$ & 22.794 & 22.820 & 21.188 & 19.897 \\
$9 / 5 / 15$ & 22.749 & 22.400 & 21.110 & 19.016 \\
$10 / 5 / 15$ & 22.708 & 22.366 & 21.102 & 19.000 \\
$11 / 5 / 15$ & 22.688 & 22.363 & 20.001 & 18.582 \\
$11 / 5 / 15$ & 22.645 & 22.358 & 20.668 & 18.133 \\
$12 / 5 / 15$ & 22.617 & 22.351 & 20.183 & 17.674 \\
$13 / 5 / 15$ & 22.585 & 22.346 & 20.112 & 17.611 \\
$14 / 5 / 15$ & 22.500 & 22.341 & 20.011 & 17.489 \\
$15 / 5 / 15$ & 22.466 & 22.100 & 19.600 & 17.066 \\
$16 / 5 / 15$ & 20.771 & 19.886 & 16.981 & 14.591 \\
$17 / 5 / 15$ & 18.708 & 17.237 & 13.660 & 11.796 \\
$18 / 5 / 15$ & 16.931 & 16.944 & 10.814 & 8.844 \\
& & & & \\
$19 / 5 / 15$ & 15.884 & 14.188 & 7.716 & 5.533 \\
$20 / 5 / 15$ & 14.930 & 11.894 & 5.842 & 2.994 \\
$21 / 5 / 15$ & 13.533 & 9.629 & 3.770 & 1.877 \\
$22 / 5 / 15$ & 11.220 & 6.535 & 1.077 & 1.087 \\
$23 / 5 / 15$ & 9.781 & 3.358 & 0.933 & 0.621 \\
$24 / 5 / 12$ & 7.308 & 1.988 & 0.526 & 0.339 \\
\hline
\end{tabular}

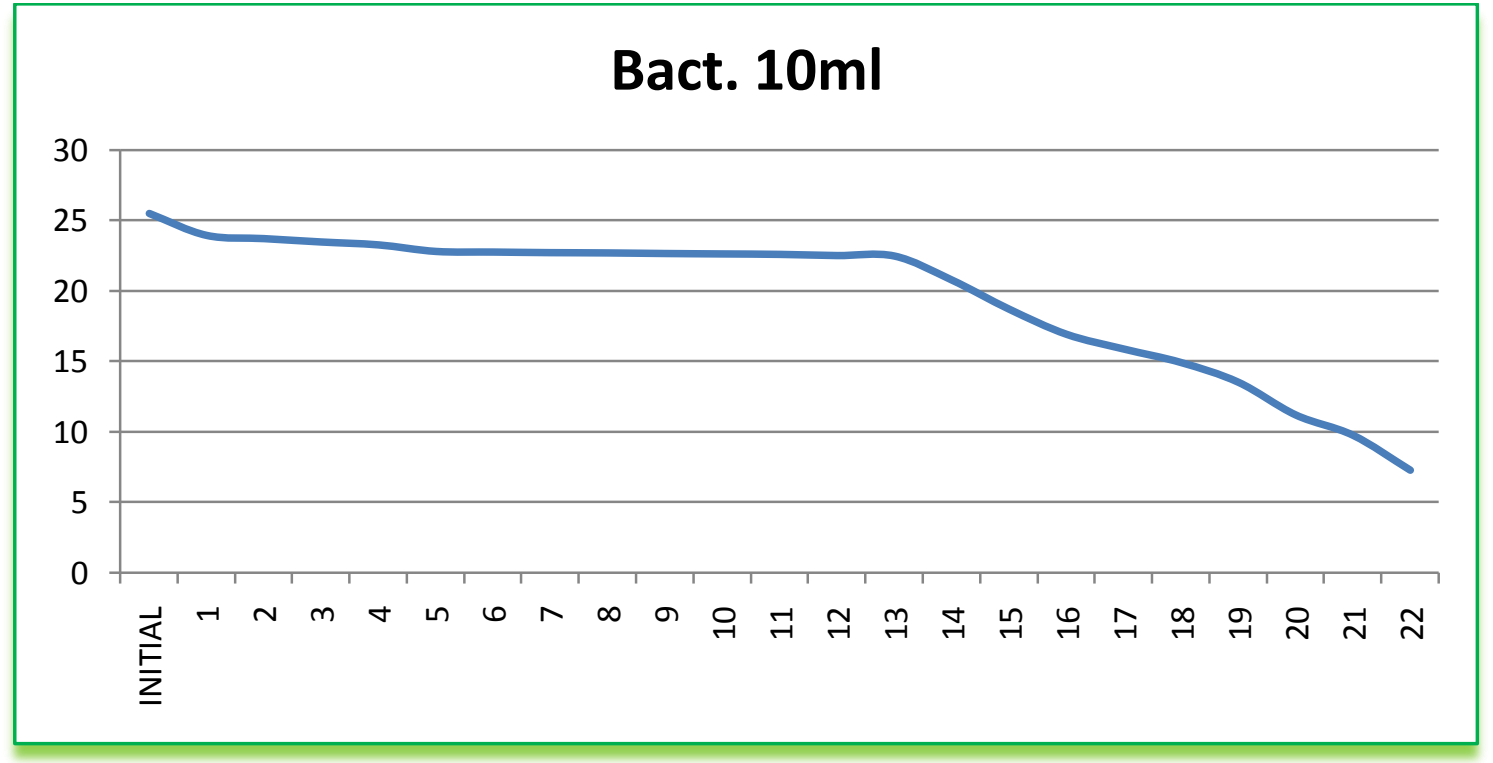

Fig I-E: Bioregeneration @ 10ml of bacteria 


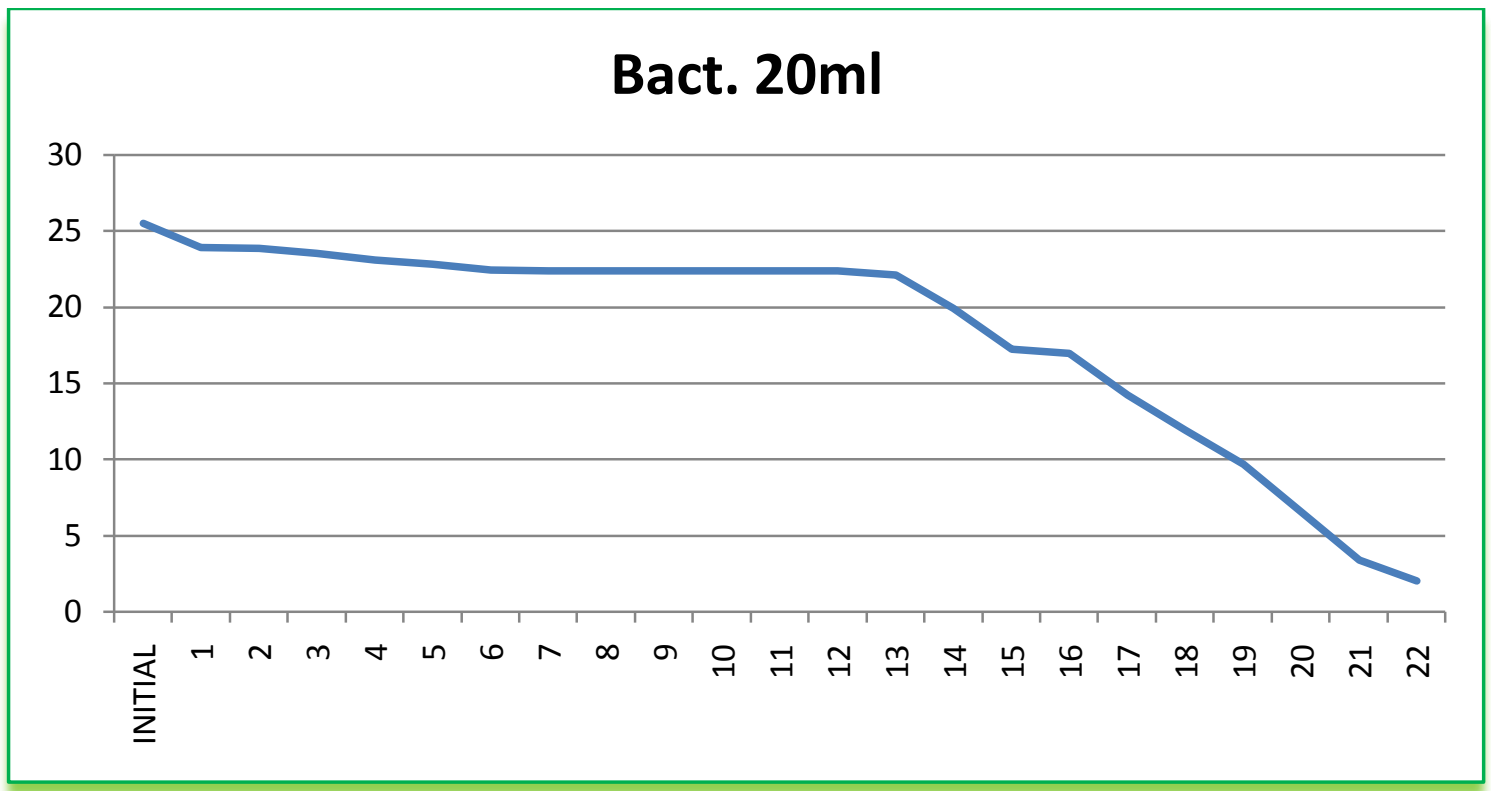

Fig I-F: Bioregeneration @ 20ml of bacteria

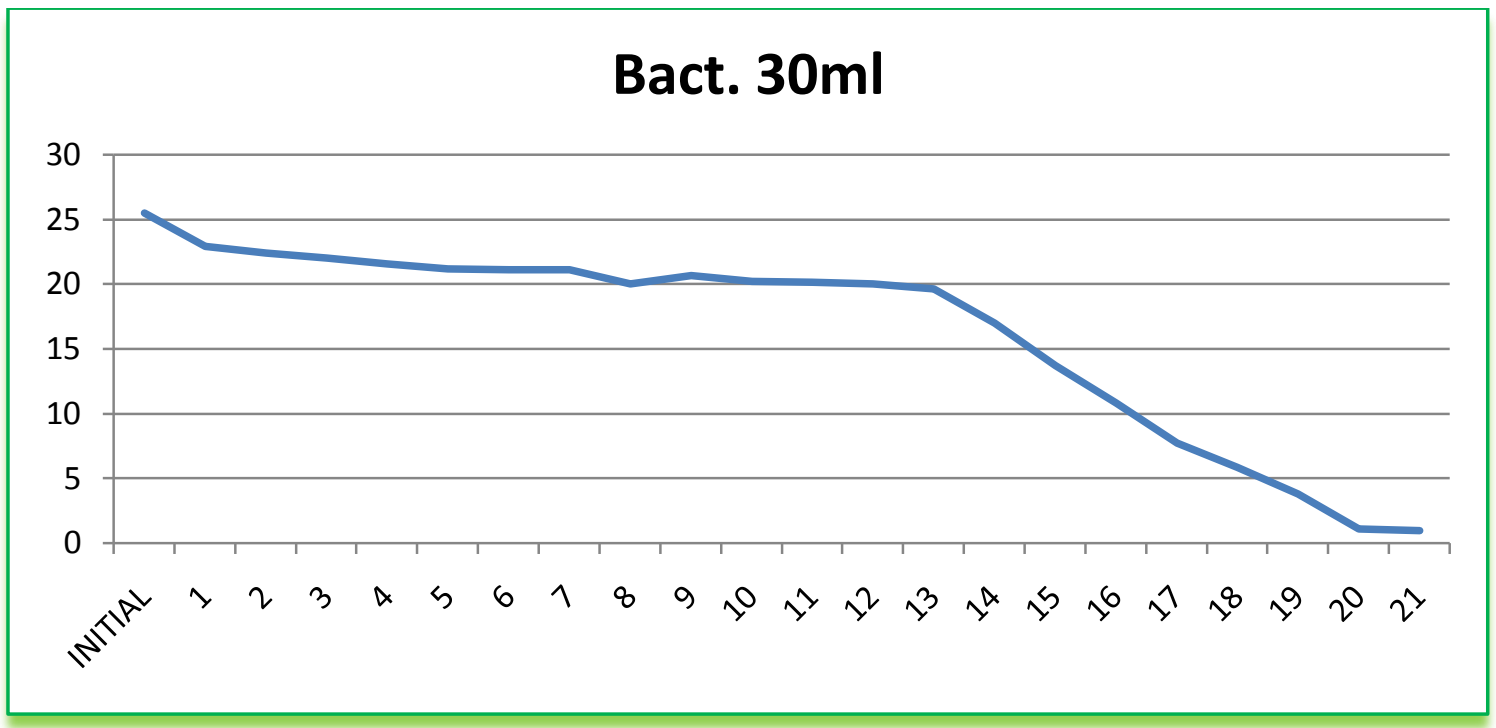

Fig I-G: Bioregeneration @ 30ml of bacteria

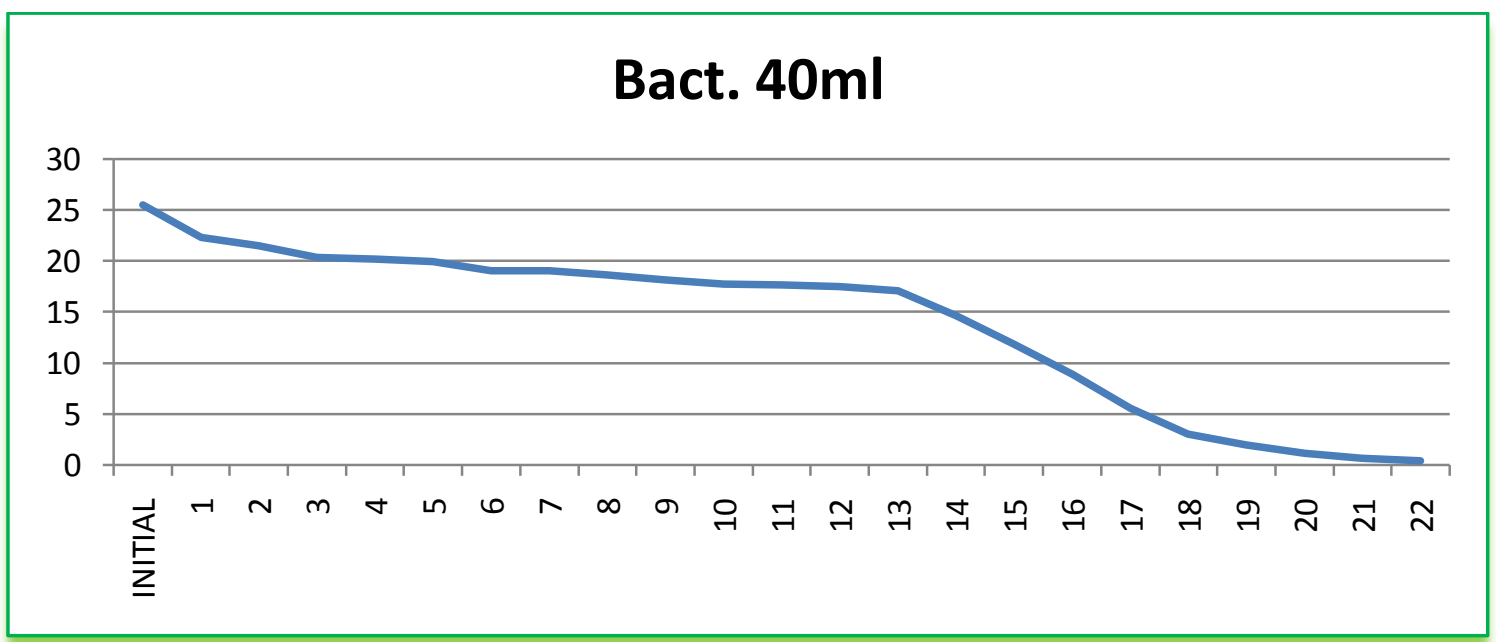


Fig I-H: Bioregeneration@ @4ml of bacteria

Table I-B: Bioregeneration at Different Temperatures

\begin{tabular}{cccc}
\hline & $\mathbf{3 5}^{\mathbf{0}} \mathbf{C}$ & $\mathbf{2 5}^{\mathbf{0}} \mathbf{C}$ & $\mathbf{2 7}^{\mathbf{0}} \mathbf{C}$ \\
\hline INITIAL THC & 24.349 & 24.349 & 24.349 \\
$6 / 4 / 12$ & 20.934 & 20.188 & 24.344 \\
$7 / 4 / 12$ & 19.880 & 18.835 & 24.338 \\
$8 / 4 / 12$ & 19.839 & 18.196 & 24.334 \\
$9 / 4 / 12$ & 19.274 & 17.886 & 24.214 \\
$10 / 4 / 12$ & 19.175 & 17.513 & 24.166 \\
$11 / 4 / 12$ & 17.800 & 15.159 & 22.616 \\
$12 / 4 / 12$ & 15.734 & 12.228 & 18.980 \\
$13 / 4 / 12$ & 13.990 & 9.741 & 16.841 \\
$14 / 4 / 12$ & 13.400 & 9.212 & 15.002 \\
$15 / 4 / 12$ & 12.656 & 8.884 & 13.629 \\
$16 / 4 / 12$ & 11.172 & 7.808 & 12.254 \\
$17 / 4 / 12$ & 9.534 & 5.791 & 11.060 \\
$18 / 4 / 12$ & 7.877 & 4.664 & 8.361 \\
$19 / 4 / 12$ & 6.690 & 3.990 & 6.574 \\
$20 / 4 / 12$ & 5.880 & 2.830 & 5.080 \\
$21 / 4 / 12$ & 4.109 & 2.526 & 3.208 \\
$22 / 4 / 12$ & 3.770 & 1.944 & 2.894 \\
$23 / 4 / 12$ & 3.502 & 1.606 & 1.979 \\
$24 / 4 / 12$ & 2.183 & 1.207 & 1.526 \\
$25 / 4 / 12$ & 1.774 & 0.962 & 0.880 \\
$26 / 4 / 12$ & 1.535 & 0.785 & 0.599 \\
\hline
\end{tabular}

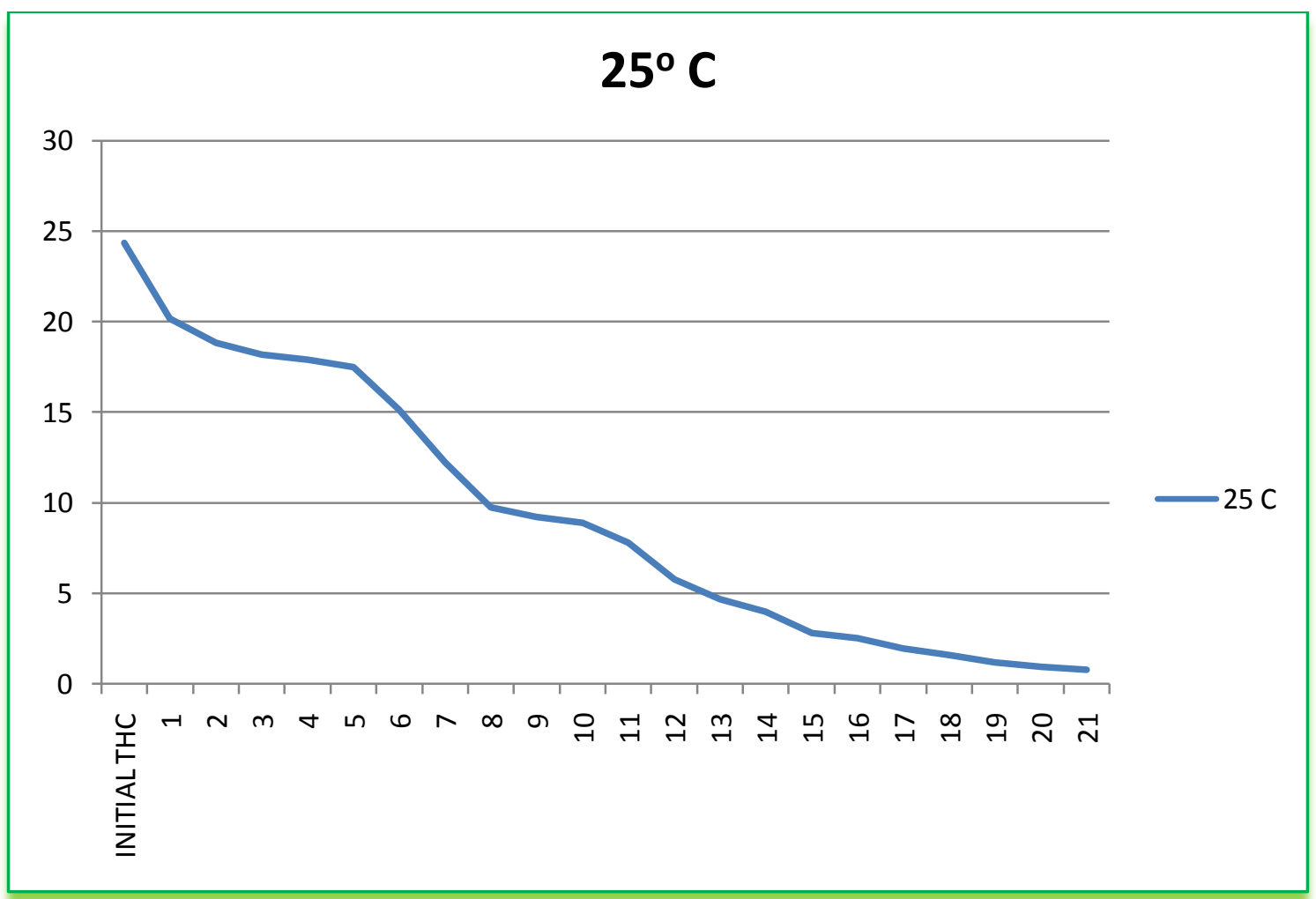

Fig I-J: Bioregeneration experiment at $25^{\circ} \mathrm{C}$ 


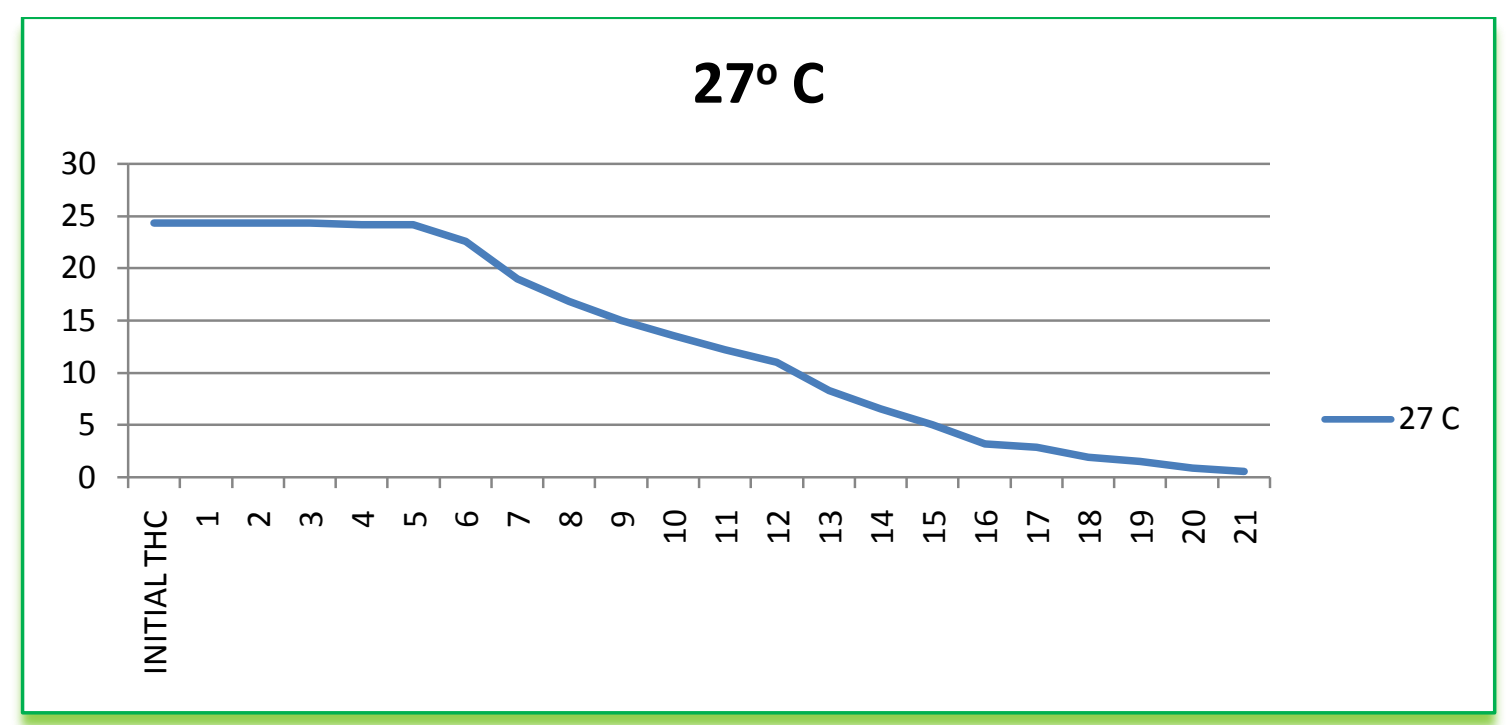

Fig I-K: Bioregeneration experiment at $27^{\circ} \mathrm{C}$

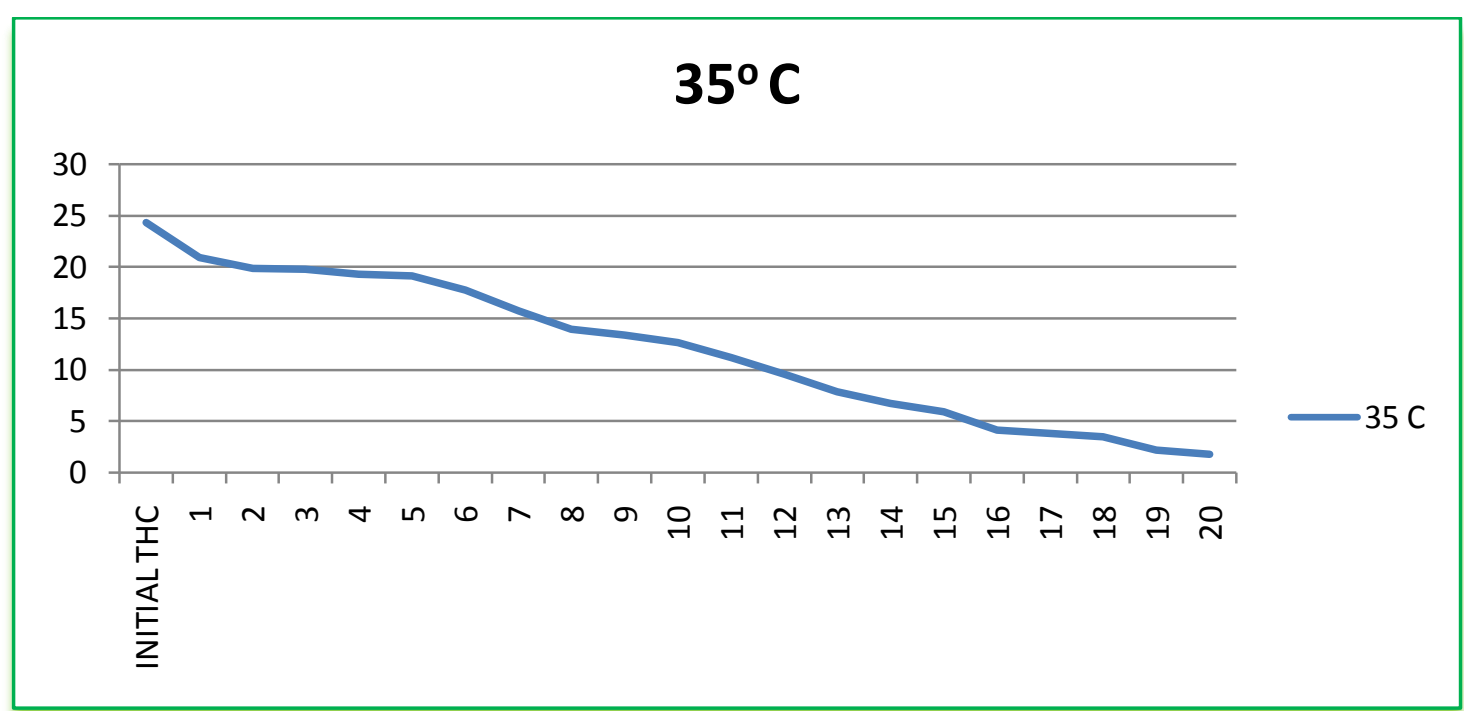

Fig I-L: Bioregeneration experiment at $35^{\circ} \mathrm{C}$

Table I-C: Further bioregeneration at higher temperatures

\begin{tabular}{ccc}
\hline & Table I-C: Further bioregeneration at higher temperatures \\
\hline INITIAL & $\mathbf{4 0}^{\mathbf{0}} \mathbf{c}$ & $\mathbf{4 5}^{\mathbf{0}} \mathbf{c}$ \\
$4 / 5 / 15$ & 1.535 & 1.535 \\
$5 / 5 / 15$ & 1.336 & 1.501 \\
$6 / 5 / 15$ & 1.334 & 1.486 \\
$7 / 5 / 15$ & 1.330 & 1.487 \\
$8 / 5 / 15$ & 1.309 & 1.460 \\
$9 / 5 / 15$ & 1.304 & 1.463 \\
$10 / 5 / 15$ & 1.230 & 1.451 \\
$11 / 5 / 15$ & 1.186 & 1.447 \\
$12 / 5 / 15$ & 1.153 & 1.444 \\
$13 / 5 / 15$ & 1.128 & 1.442 \\
$14 / 5 / 15$ & 1.081 & 1.440 \\
$15 / 5 / 15$ & 1.049 & 1.438 \\
$16 / 5 / 15$ & 1.016 & 1.414 \\
& 0.901 & 0.938
\end{tabular}




$\begin{array}{lll}17 / 5 / 15 & 0.722 & 0.862 \\ 18 / 5 / 15 & 0.697 & 0.840 \\ 19 / 5 / 15 & 0.583 & 0.661 \\ 20 / 5 / 15 & 0.550 & 0.609 \\ 21 / 5 / 15 & 0.536 & 0.597 \\ 22 / 5 / 15 & 0.387 & 0.331 \\ 23 / 5 / 15 & 0.188 & 0.162 \\ 24 / 5 / 12 & 0.142 & 0.130\end{array}$

No. of days $=21$

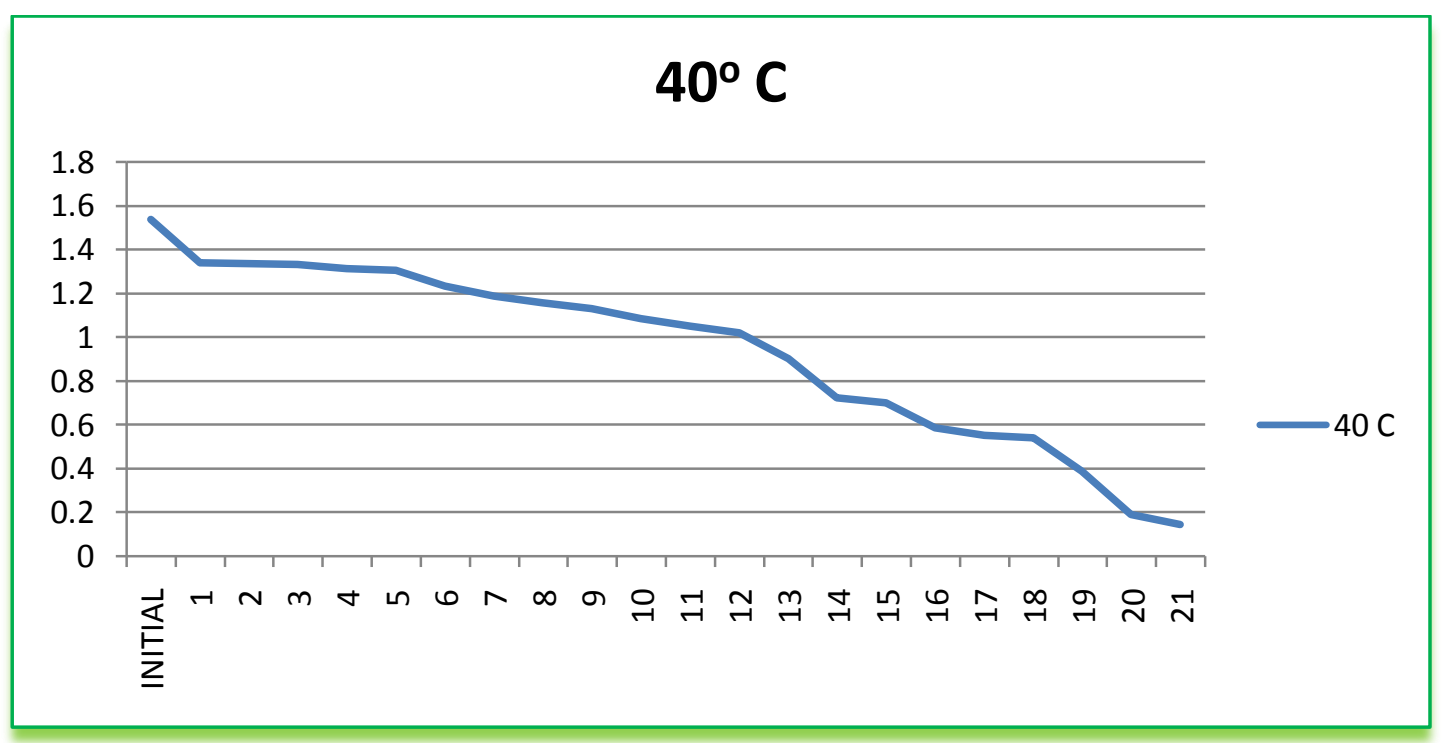

Fig I-M: Further bioregeneration at $40^{\circ} \mathrm{C}$

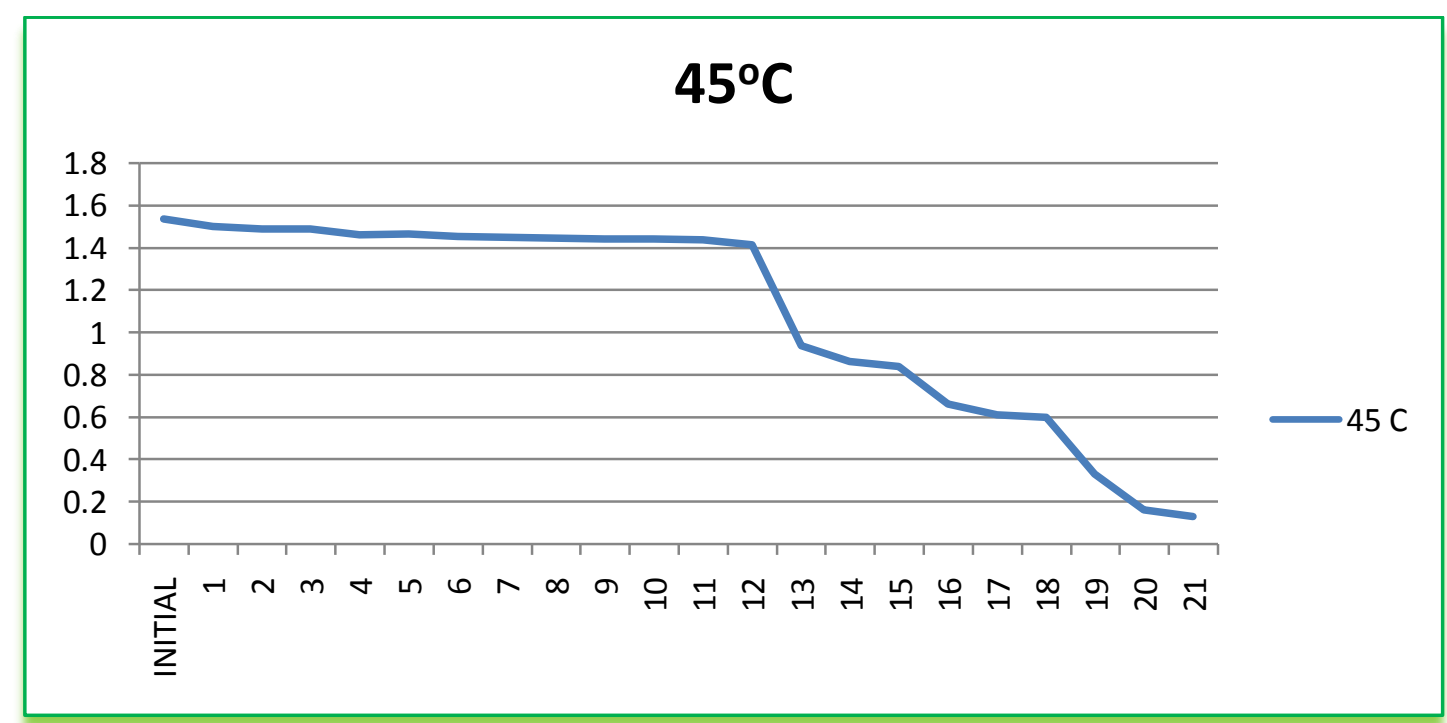

Fig I-N: Further Bioregeneration at $45^{\circ} \mathrm{C}$

Table I-D: Model simulation at $10 \mathrm{ml}$ of bacteria

\begin{tabular}{rrrrrrrrrr}
\hline S/No & Days & t & \multicolumn{1}{c}{ CAO } & CA & rA & R & CA $^{2}$ & R.CA & rm \\
\hline 1 & 4 & 24 & 25.48 & 23.93 & 0.064583 & 370.529 & 572.6449 & 8866.76 & 0.077582 \\
2 & 5 & 48 & 25.48 & 23.701 & 0.037063 & 639.4874 & 561.7374 & 15156.49 & 0.043619 \\
3 & 6 & 72 & 25.48 & 23.462 & 0.028028 & 837.0981 & 550.4654 & 19640 & 0.029753 \\
4 & 7 & 96 & 25.48 & 23.255 & 0.023177 & 1003.362 & 540.795 & 23333.18 & 0.023234 \\
5 & 8 & 120 & 25.48 & 22.794 & 0.022383 & 1018.347 & 519.5664 & 23212.2 & 0.015466 \\
6 & 9 & 144 & 25.48 & 22.749 & 0.018965 & 1199.508 & 517.517 & 27287.6 & 0.014967 \\
\hline \multicolumn{7}{c}{ www.iosrjournals.org } & & & $63 \mid$ Page
\end{tabular}


Experimental Studies On Bioregeneration Of Activated Carbon Contaminated With Hydrocarbon

\begin{tabular}{cccccccccc}
7 & 10 & 168 & 25.48 & 22.708 & 0.0165 & 1376.242 & 515.6533 & 31251.71 & 0.014537 \\
8 & 11 & 192 & 25.48 & 22.645 & 0.014766 & 1533.63 & 512.796 & 34729.04 & 0.013921 \\
9 & 12 & 216 & 25.48 & 22.617 & 0.013255 & 1706.347 & 511.5287 & 38592.45 & 0.013663 \\
10 & 13 & 240 & 25.48 & 22.585 & 0.012063 & 1872.332 & 510.0822 & 42286.61 & 0.013378 \\
11 & 14 & 264 & 25.48 & 22.5 & 0.011288 & 1993.289 & 506.25 & 44848.99 & 0.012673 \\
12 & 15 & 288 & 25.48 & 22.466 & 0.010465 & 2146.718 & 504.7212 & 48228.17 & 0.01241 \\
13 & 16 & 312 & 25.48 & 20.771 & 0.015093 & 1376.206 & 431.4344 & 28585.17 & 0.018499 \\
14 & 17 & 336 & 25.48 & 18.708 & 0.020155 & 928.2174 & 349.9893 & 17365.09 & 0.019457 \\
15 & 18 & 360 & 25.48 & 16.931 & 0.023747 & 712.9676 & 286.6588 & 12071.25 & 0.020583 \\
16 & 19 & 384 & 25.48 & 15.884 & 0.02499 & 635.6248 & 252.3015 & 10096.27 & 0.021444 \\
17 & 20 & 408 & 25.48 & 14.93 & 0.025858 & 577.3877 & 222.9049 & 8620.398 & 0.022414 \\
18 & 21 & 432 & 25.48 & 13.533 & 0.027655 & 489.3493 & 183.1421 & 6622.364 & 0.024301 \\
19 & 22 & 456 & 25.48 & 11.22 & 0.031272 & 358.7882 & 125.8884 & 4025.604 & 0.029838 \\
20 & 23 & 480 & 25.48 & 9.781 & 0.032706 & 299.056 & 95.66796 & 2925.067 & 0.037117 \\
21 & 24 & 504 & 25.48 & 7.308 & 0.036056 & 202.6872 & 53.40686 & 1481.238 & 0.10416 \\
\hline
\end{tabular}

Table I-E: Model simulation at $20 \mathrm{ml}$ of bacteria

\begin{tabular}{cccccccccc}
\hline S/No & & $\mathbf{t}$ & $\mathbf{C A O}$ & $\mathbf{C A}$ & $\mathbf{r A}$ & $\mathbf{R}$ & $\mathbf{C A}^{\mathbf{2}}$ & $\mathbf{R . C A}$ & $\mathbf{r m}$ \\
\hline 1 & 4 & 24 & 25.48 & 23.88 & 0.066667 & 358.2 & 570.2544 & 8553.816 & 0.049851519 \\
2 & 5 & 48 & 25.48 & 23.82 & 0.034583 & 688.7711 & 567.3924 & 16406.53 & 0.045902372 \\
3 & 6 & 72 & 25.48 & 23.51 & 0.027361 & 859.2487 & 552.7201 & 20200.94 & 0.032422989 \\
4 & 7 & 96 & 25.48 & 23.07 & 0.025104 & 918.971 & 532.2249 & 21200.66 & 0.022667899 \\
5 & 8 & 120 & 25.48 & 22.82 & 0.022167 & 1029.474 & 520.7524 & 23492.59 & 0.019273498 \\
6 & 9 & 144 & 25.48 & 22.4 & 0.021389 & 1047.273 & 501.76 & 23458.91 & 0.01530741 \\
7 & 10 & 168 & 25.48 & 22.366 & 0.018536 & 1206.644 & 500.238 & 26987.79 & 0.015051586 \\
8 & 11 & 192 & 25.48 & 22.358 & 0.01626 & 1374.996 & 499.8802 & 30742.15 & 0.014992519 \\
9 & 12 & 216 & 25.48 & 22.357 & 0.014458 & 1546.305 & 499.8354 & 34570.75 & 0.014985166 \\
10 & 13 & 240 & 25.48 & 22.346 & 0.013058 & 1711.244 & 499.3437 & 38239.47 & 0.014904706 \\
11 & 14 & 264 & 25.48 & 22.341 & 0.01189 & 1878.95 & 499.1203 & 41977.62 & 0.014868392 \\
12 & 15 & 288 & 25.48 & 22.1 & 0.011736 & 1883.077 & 488.41 & 41616 & 0.01329029 \\
13 & 16 & 312 & 25.48 & 19.886 & 0.017929 & 1109.123 & 395.453 & 22056.01 & 0.022392794 \\
14 & 17 & 336 & 25.48 & 17.237 & 0.024533 & 702.6122 & 297.1142 & 12110.93 & 0.023047841 \\
15 & 18 & 360 & 25.48 & 16.944 & 0.023711 & 714.6017 & 287.0991 & 12108.21 & 0.023135696 \\
16 & 19 & 384 & 25.48 & 14.188 & 0.029406 & 482.4825 & 201.2993 & 6845.461 & 0.02418938 \\
17 & 20 & 408 & 25.48 & 11.894 & 0.033299 & 357.1877 & 141.4672 & 4248.39 & 0.025570292 \\
18 & 21 & 432 & 25.48 & 9.629 & 0.036692 & 262.4269 & 92.71764 & 2526.908 & 0.027886339 \\
19 & 22 & 456 & 25.48 & 6.535 & 0.041546 & 157.2953 & 42.70623 & 1027.925 & 0.035991126 \\
20 & 23 & 480 & 25.48 & 3.358 & 0.046088 & 72.8614 & 11.27616 & 244.6686 & 0.249507322 \\
21 & 24 & 504 & 25.48 & 1.988 & 0.046611 & 42.65077 & 3.952144 & 84.78974 & -0.03367417 \\
\hline
\end{tabular}

Table I-F: Model simulation at $30 \mathrm{ml}$ of bacteria

\begin{tabular}{cccccccccl}
\hline S/No & & $\mathbf{t}$ & $\mathbf{C A O}$ & $\mathbf{C A}$ & $\mathbf{r A}$ & $\mathbf{R}$ & CA $^{\mathbf{2}}$ & $\mathbf{R} . \mathbf{C A}$ & rm \\
\hline 1 & 4 & 24 & 25.48 & 22.914 & 0.106917 & 214.3164 & 525.0514 & 4910.847 & 0.095968 \\
2 & 5 & 48 & 25.48 & 22.401 & 0.064146 & 349.2199 & 501.8048 & 7822.874 & 0.062206 \\
3 & 6 & 72 & 25.48 & 21.987 & 0.048514 & 453.2104 & 483.4282 & 9964.738 & 0.048003 \\
4 & 7 & 96 & 25.48 & 21.533 & 0.041115 & 523.7314 & 463.6701 & 11277.51 & 0.038083 \\
5 & 8 & 120 & 25.48 & 21.188 & 0.035767 & 592.3952 & 448.9313 & 12551.67 & 0.032747 \\
6 & 9 & 144 & 25.48 & 21.11 & 0.030347 & 695.6156 & 445.6321 & 14684.44 & 0.031722 \\
7 & 10 & 168 & 25.48 & 21.102 & 0.02606 & 809.7615 & 445.2944 & 17087.59 & 0.03162 \\
8 & 11 & 192 & 25.48 & 20.668 & 0.025063 & 824.6584 & 427.1662 & 17044.04 & 0.026841 \\
9 & 12 & 216 & 25.48 & 20.183 & 0.024523 & 823.0183 & 407.3535 & 16610.98 & 0.022812 \\
10 & 13 & 240 & 25.48 & 20.112 & 0.022367 & 899.1952 & 404.4925 & 18084.61 & 0.022309 \\
11 & 14 & 264 & 25.48 & 20.011 & 0.020716 & 965.9726 & 400.4401 & 19330.08 & 0.021624 \\
12 & 15 & 288 & 25.48 & 19.6 & 0.020417 & 960 & 384.16 & 18816 & 0.019166 \\
13 & 16 & 312 & 25.48 & 16.981 & 0.02724 & 623.3759 & 288.3544 & 10585.55 & 0.032033 \\
14 & 17 & 336 & 25.48 & 13.66 & 0.035179 & 388.3046 & 186.5956 & 5304.24 & 0.032658
\end{tabular}


Experimental Studies On Bioregeneration Of Activated Carbon Contaminated With Hydrocarbon

\begin{tabular}{cccccccccc}
\hline 15 & 18 & 360 & 25.48 & 10.814 & 0.040739 & 265.4466 & 116.9426 & 2870.54 & 0.033539 \\
16 & 19 & 384 & 25.48 & 7.716 & 0.04626 & 166.7949 & 59.53666 & 1286.989 & 0.035378 \\
17 & 20 & 408 & 25.48 & 5.842 & 0.048132 & 121.3737 & 34.12896 & 709.0649 & 0.037692 \\
18 & 21 & 432 & 25.48 & 3.77 & 0.050255 & 75.01796 & 14.2129 & 282.8177 & 0.044239 \\
19 & 22 & 456 & 25.48 & 1.077 & 0.053515 & 20.12507 & 1.159929 & 21.6747 & -0.19693 \\
20 & 23 & 480 & 25.48 & 0.933 & 0.05114 & 18.24418 & 0.870489 & 17.02182 & -0.09042 \\
21 & 24 & 504 & 25.48 & 0.526 & 0.049512 & 10.62371 & 0.276676 & 5.58807 & -0.02189 \\
\hline
\end{tabular}

Table I-G: Model simulation at 40ml of bacteria

\begin{tabular}{cccccccccc}
\hline S/No & & $\mathbf{t}$ & CAO & CA & rA & R & CA $^{2}$ & R.CA & rm \\
\hline 1 & 4 & 24 & 25.48 & 22.271 & 0.133708 & 166.564 & 495.9974 & 3709.548 & 0.116643 \\
2 & 5 & 48 & 25.48 & 21.508 & 0.08275 & 259.9154 & 462.5941 & 5590.261 & 0.086599 \\
3 & 6 & 72 & 25.48 & 20.333 & 0.071486 & 284.4329 & 413.4309 & 5783.374 & 0.060371 \\
4 & 7 & 96 & 25.48 & 20.164 & 0.055375 & 364.1354 & 406.5869 & 7342.427 & 0.05769 \\
5 & 8 & 120 & 25.48 & 19.897 & 0.046525 & 427.6625 & 395.8906 & 8509.202 & 0.053831 \\
6 & 9 & 144 & 25.48 & 19.016 & 0.044889 & 423.6238 & 361.6083 & 8055.629 & 0.043622 \\
7 & 10 & 168 & 25.48 & 19 & 0.038571 & 492.5926 & 361 & 9359.259 & 0.043465 \\
8 & 11 & 192 & 25.48 & 18.133 & 0.038266 & 473.8718 & 328.8057 & 8592.717 & 0.036094 \\
9 & 12 & 216 & 25.48 & 17.674 & 0.036139 & 489.0576 & 312.3703 & 8643.605 & 0.032916 \\
10 & 13 & 240 & 25.48 & 17.611 & 0.032788 & 537.1254 & 310.1473 & 9459.316 & 0.032512 \\
11 & 14 & 264 & 25.48 & 17.489 & 0.030269 & 577.787 & 305.8651 & 10104.92 & 0.031748 \\
12 & 15 & 288 & 25.48 & 17.066 & 0.029215 & 584.1464 & 291.2484 & 9969.043 & 0.029288 \\
13 & 16 & 312 & 25.48 & 14.591 & 0.034901 & 418.0726 & 212.8973 & 6100.097 & 0.038516 \\
14 & 17 & 336 & 25.48 & 11.796 & 0.040726 & 289.6416 & 139.1456 & 3416.613 & 0.038961 \\
15 & 18 & 360 & 25.48 & 8.844 & 0.046211 & 191.3825 & 78.21634 & 1692.587 & 0.03976 \\
16 & 19 & 384 & 25.48 & 5.533 & 0.051945 & 106.5159 & 30.61409 & 589.3523 & 0.041813 \\
17 & 20 & 408 & 25.48 & 2.994 & 0.055113 & 54.325 & 8.964036 & 162.6491 & 0.047348 \\
18 & 21 & 432 & 25.48 & 1.877 & 0.054637 & 34.35428 & 3.523129 & 64.48298 & 0.057162 \\
19 & 22 & 456 & 25.48 & 1.087 & 0.053493 & 20.32026 & 1.181569 & 22.08812 & 0.095872 \\
20 & 23 & 480 & 25.48 & 0.621 & 0.05179 & 11.99083 & 0.385641 & 7.446304 & -0.46229 \\
21 & 24 & 504 & 25.48 & 0.339 & 0.049883 & 6.795911 & 0.114921 & 2.303814 & -0.03759 \\
\hline
\end{tabular}

Table I-H: Model simulation at $25^{\circ} \mathrm{C}$ temperature

\begin{tabular}{|c|c|c|c|c|c|c|c|c|c|}
\hline S/No & Days & $\mathbf{t}$ & CAO & CA & rA & $\mathbf{R}$ & $C A^{2}$ & R.CA & $\mathrm{rm}$ \\
\hline 1 & 4 & 24 & 24.349 & 20.188 & 0.173375 & 116.4412 & 407.5553 & 2350.716 & 0.083672 \\
\hline 2 & 5 & 48 & 24.349 & 18.835 & 0.114875 & 163.9608 & 354.7572 & 3088.202 & 0.083117 \\
\hline 3 & 6 & 72 & 24.349 & 18.196 & 0.085458 & 212.9225 & 331.0944 & 3874.337 & 0.08283 \\
\hline 4 & 7 & 96 & 24.349 & 17.886 & 0.067323 & 265.6748 & 319.909 & 4751.859 & 0.082684 \\
\hline 5 & 8 & 120 & 24.349 & 17.513 & 0.056967 & 307.4254 & 306.7052 & 5383.941 & 0.082502 \\
\hline 6 & 9 & 144 & 24.349 & 15.159 & 0.063819 & 237.5295 & 229.7953 & 3600.71 & 0.081172 \\
\hline 7 & 10 & 168 & 24.349 & 12.228 & 0.072149 & 169.483 & 149.524 & 2072.439 & 0.078904 \\
\hline 8 & 11 & 192 & 24.349 & 9.741 & 0.076083 & 128.0307 & 94.88708 & 1247.147 & 0.076096 \\
\hline 9 & 12 & 216 & 24.349 & 9.212 & 0.070079 & 131.4522 & 84.86094 & 1210.938 & 0.075339 \\
\hline 10 & 13 & 240 & 24.349 & 8.884 & 0.064438 & 137.87 & 78.92546 & 1224.837 & 0.074833 \\
\hline 11 & 14 & 264 & 24.349 & 7.808 & 0.062655 & 124.6183 & 60.96486 & 973.02 & 0.072937 \\
\hline 12 & 15 & 288 & 24.349 & 5.791 & 0.064438 & 89.87003 & 33.53568 & 520.4373 & 0.067983 \\
\hline 13 & 16 & 312 & 24.349 & 4.664 & 0.063093 & 73.92268 & 21.7529 & 344.7754 & 0.063922 \\
\hline 14 & 17 & 336 & 24.349 & 3.99 & 0.060592 & 65.84999 & 15.9201 & 262.7415 & 0.060771 \\
\hline 15 & 18 & 360 & 24.349 & 2.83 & 0.059775 & 47.34421 & 8.0089 & 133.9841 & 0.053316 \\
\hline 16 & 19 & 384 & 24.349 & 2.526 & 0.056831 & 44.44778 & 6.380676 & 112.2751 & 0.05074 \\
\hline 17 & 20 & 408 & 24.349 & 1.944 & 0.054914 & 35.40067 & 3.779136 & 68.8189 & 0.044717 \\
\hline 18 & 21 & 432 & 24.349 & 1.606 & 0.052646 & 30.50574 & 2.579236 & 48.99222 & 0.040343 \\
\hline 19 & 22 & 456 & 24.349 & 1.207 & 0.05075 & 23.78325 & 1.456849 & 28.70638 & 0.034016 \\
\hline 20 & 23 & 480 & 24.349 & 0.962 & 0.048723 & 19.7443 & 0.925444 & 18.99402 & 0.029306 \\
\hline 21 & 24 & 504 & 24.349 & 0.785 & 0.046754 & 16.79002 & 0.616225 & 13.18016 & 0.025398 \\
\hline
\end{tabular}


Experimental Studies On Bioregeneration Of Activated Carbon Contaminated With Hydrocarbon

Table I-J: Model simulation at $27^{\circ} \mathrm{C}$ temperature

\begin{tabular}{cccccccccc}
\hline S/No & & $\mathbf{t}$ & $\mathbf{C A O}$ & $\mathbf{C A}$ & $\mathbf{r A}$ & $\mathbf{R}$ & CA $^{2}$ & $\mathbf{R} . \mathbf{C A}$ & rm \\
\hline 1 & 4 & 24 & 24.349 & 24.344 & 0.000208 & 116851.2 & 592.6303 & 2844626 & 0.000491861 \\
2 & 5 & 48 & 24.349 & 24.338 & 0.000229 & 106202.2 & 592.3382 & 2584749 & 0.000491898 \\
3 & 6 & 72 & 24.349 & 24.334 & 0.000208 & 116803.2 & 592.1436 & 2842289 & 0.000491923 \\
4 & 7 & 96 & 24.349 & 24.214 & 0.001406 & 17218.84 & 586.3178 & 416937.1 & 0.000492682 \\
5 & 8 & 120 & 24.349 & 24.166 & 0.001525 & 15846.56 & 583.9956 & 382947.9 & 0.000492989 \\
6 & 9 & 144 & 24.349 & 22.616 & 0.012035 & 1879.229 & 511.4835 & 42500.64 & 0.000503822 \\
7 & 10 & 168 & 24.349 & 18.98 & 0.031958 & 593.8983 & 360.2404 & 11272.19 & 0.000539211 \\
8 & 11 & 192 & 24.349 & 16.841 & 0.039104 & 430.6702 & 283.6193 & 7252.917 & 0.00057089 \\
9 & 12 & 216 & 24.349 & 15.002 & 0.043273 & 346.6815 & 225.06 & 5200.916 & 0.000609863 \\
10 & 13 & 240 & 24.349 & 13.629 & 0.044667 & 305.1269 & 185.7496 & 4158.574 & 0.000650855 \\
11 & 14 & 264 & 24.349 & 12.254 & 0.045814 & 267.4705 & 150.1605 & 3277.584 & 0.000709307 \\
12 & 15 & 288 & 24.349 & 11.06 & 0.046142 & 239.693 & 122.3236 & 2651.004 & 0.000784719 \\
13 & 16 & 312 & 24.349 & 8.361 & 0.051244 & 163.1619 & 69.90632 & 1364.196 & 0.001211411 \\
14 & 17 & 336 & 24.349 & 6.574 & 0.052902 & 124.268 & 43.21748 & 816.9379 & 0.003072201 \\
15 & 18 & 360 & 24.349 & 5.08 & 0.053525 & 94.90892 & 25.8064 & 482.1373 & -0.002758757 \\
16 & 19 & 384 & 24.349 & 3.208 & 0.055055 & 58.26933 & 10.29126 & 186.928 & -0.000469696 \\
17 & 20 & 408 & 24.349 & 2.894 & 0.052586 & 55.03388 & 8.375236 & 159.2681 & -0.000377476 \\
18 & 21 & 432 & 24.349 & 1.979 & 0.051782 & 38.21761 & 3.916441 & 75.63266 & -0.000195843 \\
19 & 22 & 456 & 24.349 & 1.526 & 0.05005 & 30.48924 & 2.328676 & 46.52659 & -0.000134899 \\
20 & 23 & 480 & 24.349 & 0.88 & 0.048894 & 17.99821 & 0.7744 & 15.83843 & $-6.75175 \mathrm{E}-05$ \\
21 & 24 & 504 & 24.349 & 0.599 & 0.047123 & 12.71141 & 0.358801 & 7.614135 & $-4.3461 \mathrm{E}-05$ \\
\hline
\end{tabular}

Table I-K: Model simulation at $35^{\circ} \mathrm{C}$ temperature

\begin{tabular}{cccccccccc}
\hline S/No & & $\mathbf{t}$ & $\mathbf{C A O}$ & $\mathbf{C A}$ & $\mathbf{r A}$ & $\mathbf{R}$ & CA $^{2}$ & R.CA & rm \\
\hline 1 & 4 & 24 & 24.349 & 20.934 & 0.142292 & 147.1204 & 438.2324 & 3079.817 & 0.06038 \\
2 & 5 & 48 & 24.349 & 19.88 & 0.093104 & 213.5243 & 395.2144 & 4244.863 & 0.060113 \\
3 & 6 & 72 & 24.349 & 19.839 & 0.062639 & 316.7202 & 393.5859 & 6283.412 & 0.060102 \\
4 & 7 & 96 & 24.349 & 19.274 & 0.052865 & 364.5919 & 371.4871 & 7027.145 & 0.059948 \\
5 & 8 & 120 & 24.349 & 19.175 & 0.043117 & 444.7236 & 367.6806 & 8527.575 & 0.05992 \\
6 & 9 & 144 & 24.349 & 17.8 & 0.045479 & 391.388 & 316.84 & 6966.706 & 0.059503 \\
7 & 10 & 168 & 24.349 & 15.734 & 0.05128 & 306.8267 & 247.5588 & 4827.611 & 0.058755 \\
8 & 11 & 192 & 24.349 & 13.99 & 0.053953 & 259.2992 & 195.7201 & 3627.595 & 0.057972 \\
9 & 12 & 216 & 24.349 & 13.4 & 0.05069 & 264.3529 & 179.56 & 3542.329 & 0.057667 \\
10 & 13 & 240 & 24.349 & 12.656 & 0.048721 & 259.7657 & 160.1743 & 3287.594 & 0.057247 \\
11 & 14 & 264 & 24.349 & 11.172 & 0.049913 & 223.83 & 124.8136 & 2500.629 & 0.056267 \\
12 & 15 & 288 & 24.349 & 9.534 & 0.051441 & 185.3386 & 90.89716 & 1767.019 & 0.054889 \\
13 & 16 & 312 & 24.349 & 7.877 & 0.052795 & 149.2001 & 62.04713 & 1175.249 & 0.053027 \\
14 & 17 & 336 & 24.349 & 6.69 & 0.052557 & 127.2915 & 44.7561 & 851.5799 & 0.051251 \\
15 & 18 & 360 & 24.349 & 5.88 & 0.051303 & 114.6137 & 34.5744 & 673.9284 & 0.049729 \\
16 & 19 & 384 & 24.349 & 4.109 & 0.052708 & 77.95731 & 16.88388 & 320.3266 & 0.044974 \\
17 & 20 & 408 & 24.349 & 3.77 & 0.050439 & 74.74416 & 14.2129 & 281.7855 & 0.043726 \\
18 & 21 & 432 & 24.349 & 3.502 & 0.048257 & 72.56987 & 12.264 & 254.1397 & 0.042629 \\
19 & 22 & 456 & 24.349 & 2.183 & 0.04861 & 44.90878 & 4.765489 & 98.03587 & 0.035134 \\
20 & 23 & 480 & 24.349 & 1.774 & 0.047031 & 37.7196 & 3.147076 & 66.91457 & 0.03172 \\
21 & 24 & 504 & 24.349 & 1.535 & 0.045266 & 33.91076 & 2.356225 & 52.05301 & 0.02935 \\
\hline
\end{tabular}

